\title{
Article \\ Effect of Stakeholders-Oriented Behavior on the Performance of Sustainable Business
}

\author{
Carlos Ferro-Soto ${ }^{1, *}$, Luz Amparo Macías-Quintana ${ }^{2}$ and Paula Vázquez-Rodríguez ${ }^{3}$ (i) \\ 1 Department of Business Organization and Marketing, University of Vigo, Campus Vigo, \\ 36310 Vigo-Pontevedra, Spain ${ }^{2}$ Superintendence of Companies (Colombian Government), El Dorado Av. \\ \# 51-58 Bogotá, Colombia; luzM@supersociedades.gov.co \\ 3 Department of Business Organization and Marketing, University of Santiago de Compostela, Campus Lugo, \\ 27002 Lugo, Spain; paula.vazquez@usc.es \\ * Correspondence: cferro@uvigo.es
}

Received: 11 November 2018; Accepted: 4 December 2018; Published: 11 December 2018

check for updates

\begin{abstract}
This study focuses on stakeholder-oriented behavior, throughout organizational culture and organizational behavior, and its effects on the performance of sustainable organizations managed according to Corporative Social Responsibility (CSR) criteria. The investigation demonstrates that the sustainability efforts of a wide range of stakeholders exert various effects on business performance. This investigation tests two integrated conceptual models: (a) Stakeholder Orientation Model estimates the relationships among organizational culture components and their effects on stakeholder-oriented organizational behavior. That is, it estimates the influence of values on norms and artifacts, and their effects on stakeholder-oriented organizational behavior; (b) Performance model estimates the association between stakeholder-oriented organizational behavior and financial and market performance, reputation, and commitment. Using Structural Equation Modelling, both models were estimated from primary data collected from large- and medium-sized multi-sector Colombian companies involved in business sustainability practices. The findings reveal that values are antecedents of norms, but neither values nor norms are predictors of artifacts. Furthermore, norms and artifacts exert direct effects on stakeholder-oriented organizational behavior. In turn, stakeholder-oriented organizational behaviors are predictors of both market performance and commitment. Nevertheless, stakeholder-oriented organizational behaviors are not direct antecedents of both financial performance and reputation.
\end{abstract}

Keywords: business sustainability; stakeholder orientation; organizational culture; stakeholder-oriented behavior; financial performance; market performance; reputation; commitment

\section{Introduction}

The most relevant and accelerated growth of the Corporative Social Responsibility (CSR) integral implement by companies around the world occurred in the 1990s [1]. At that time, the companies became aware that their CSR efforts were part of a win-win strategy, which was not only beneficial for society and the environment, but also for the company's financial performance [2]. This growing interest in stakeholder commitment to the decision-making process, and rising social accountability, have forced companies into exogenously driven CSR implementation [3]. In order to implement social and environmental aspects in their activities, companies have resorted to external CSR-specialized consultancy firm services [3]. In this regard, both institutional actors and consultants should foster the explicitly proactive stakeholder-oriented practices of a voluntary nature, and facilitate the exploitation of win-win advantages from CSR practice [3]. 
Managers play a key role in the strategic orientation of CSR implementation. In this regard, the managers' CSR interpretation is highly relevant, since they are the ones who exert the most influence on the organizational sustainability practices. Thus, the success of sustainability efforts depends on managers' subjective perceptions of CSR [1]. However, sustainability companies do not necessarily have the capacity to respond to the broad range of stakeholder demands and expectations, because of their limited resources. Hence, companies should prioritize the allocation of resources towards efforts that exert a major impact on the overall organizational CSR performance [1].

A growing body of literature, which has included environmental and social concerns, has experienced a research shift related to conventional performance measurement, such as economic or financial performance [4]. The implementation of sustainability practices requires the inclusion of stakeholder concerns in the organizational strategy, assessing their effects [5]. Engaging stakeholders in the organizational strategy may promote co-created sustainable value [6].

In this regard, a stakeholder orientation approach considers the whole range of stakeholder concerns, although sometimes mismatched [7-9]. These stakeholders can be persons or entities (organizations, institutions ... ) which interact with the company or have some interdependence. As a result of this relationship, stakeholders can exert an influence, either directly or indirectly, on the organization, or be affected by actions, decisions, policies, or goals of the company $[10,11]$. In this manner, sustainable businesses can satisfy or even exceed their stakeholder concerns, without compromising the demands of others [12].

Stakeholder concerns have been developed extensively throughout the stakeholder orientation approach. Stakeholder orientation is an approach developed at the heart of stakeholder theory [13-17]. According to this theory, organizations link a network of interdependent groups of stakeholders [13]. The theory focuses on stakeholder management and the inclusion of their demands as strategic factors [15]. In fact, the literature [18-21] recommends that organizations are managed to satisfy the demands of a broad group of stakeholders. Indeed, stakeholder theory supports the direct association between integrated corporate social responsibility (CSR) actions and organizational performance [22-24].

Stakeholder orientation is a broadened form of market orientation [25] and, indeed, has been developed from the market orientation approach. According to [26], market orientation only focuses on customers and competitors, and their interfunctional coordination. In this regard, stakeholder orientation enriches a marketing approach through a more expansive perspective, which includes the wellbeing of all stakeholders [7].

In addition, a learning orientation is rooted in an organizational culture, encouraging active learning through the creation and use of knowledge company-wide $[27,28]$. Therefore, organizational learning is considered a cultural aspect [29] and, consequently, has an idiosyncratic nature. For this reason, organizational learning has a relevant strategic value, since it is difficult to imitate [30], thus enhancing the competitive advantage of the company [27]. In this regard, according to Gill [31], learning orientation requires "the installation of a new organizational culture, one with new norms, assumptions, values, beliefs, and expected behavior in the organization" (p. 188).

Learning orientations are closely connected with both market and stakeholder orientations, and, in turn, these three orientations are related to CSR efforts. In fact, whereas market orientation focuses on marketplace needs and competitors, and stakeholder orientation pays attention to a broader stakeholder range, also including customers and competitors, learning orientation recognizes societal need shifts of the different stakeholders, revealing a need for new SCR efforts [1,32].

Business sustainability efforts should aim at external and internal stakeholders, as well as at the marketplace and society overall [33]. Thus, stakeholder orientation recognizes all groups with an interest in the company (employees, clients, suppliers, partners, public institutions, government, community, ... ) as a key stakeholder, rather than just those which have only financial interests in the company (shareholders) [9,29,34-40]. Svensson et al. [41] developed a stakeholder categorization, distinguishing between upstream and downstream stakeholders, the focal company, market stakeholders, and societal stakeholders. Thereby, the business goal is extended to satisfying a 
multiplicity of demands from diverse stakeholders, which are not always necessarily compatible with each other. Hence, environmental protection, promoting stable employment, improving the business environment, and local community development become key organizational goals [42].

Satisfying stakeholder concerns should contribute to achieving traditional organizational goals, namely profitability, stability, and growth [23]. Therefore, the appropriate management of diverse stakeholder expectations is key for successful business [13]. Maintaining robust stakeholder relationships contributes to creating value, since these relationships are a valuable intangible active and, consequently, a source of competitive advantage with a considerable capacity for improving business performance $[13,15,43-46]$. In this vein, Harrison and Wicks [45] point out that this performance is the overall value created, that is, the summation of all utilities generated for each stakeholder.

Since stakeholder relationships are a strategic factor, companies should develop specific action plans for each of them and invest resources for implementation [13]. Therefore, it comes down to managing business according to CSR criteria, in a dynamic way and with a capacity to adapt to diverse stakeholder visions on how to contribute to the sustainable development $[13,15,47]$. Given the multitude of stakeholders linked to the organization, stakeholder management requires a clear prioritization $[13,18]$.

Based on Homburg and Pflesser's [48] findings, Maignan et al. [8] posit that a stakeholder orientation consists of two dimensions, namely organizational culture and organizational behavior. On the one hand, organizational culture comprises values, norms, and artifacts. The artifacts operate by spreading values and norms. On the other hand, organizational behavior is composed of intelligence generation, intelligence dissemination, and responsiveness $[8,48]$. Both stakeholder-orientation components engage organizational members to pay proactive attention to satisfying diverse stakeholder expectations [8]. On balance, stakeholder orientation guides organization member behavior toward fulfilling diverse stakeholder expectations.

Stakeholder management emerges as a key competitive advantage and contributes to organizational survival [49-51]. Although Jensen [52] found that paying attention to stakeholder management occurs to the detriment of survival in competitive environments where profit-maximizing businesses compete, reality nevertheless points to stakeholder-oriented companies enhancing their financial, social, and ethical performance $[8,9,50,53,54]$. In fact, the greater the number of organizationally-integrated stakeholders, the better the company performance, as well as the understanding of and information on dominant stakeholders $[7,9,55]$.

Through CSR efforts implementation, stakeholder orientation has an impact on the purchasing behavior of customers, so the CSR activities should be conducted to satisfy the customer needs. Stakeholder orientation also focuses on competitor actions, since this stakeholder group is of crucial importance in the marketing strategy design, which are highly relevant to their success in the marketplace. Meanwhile, organizational reputation is related to the organizational capacity to generate valuable results for diverse stakeholders [56], achieved through CSR efforts conducted to satisfy the concerns of both internal and external stakeholders. High levels of organizational reputation strengthen brand value and, therefore, become a valuable source of sustainable competitive advantage. Stakeholder-oriented behavior, through organizational culture, affects organizational members' behavior [57] and, in consequence, fosters employee commitment. This sense of belonging to a company encourages organizational members to be willing to work together in order to achieve the organizational goals [38]. Therefore, these effects, which stem from stakeholder-oriented behavior, are likely to have repercussions on both market and financial performance.

Accordingly, sustainable management positively affects business performance. For Kohli and Jaworski [38,58], these positive effects are evident as either profitability, profits, sales volume, market share, and sales growth, or as teamwork spirit, employee satisfaction, and organizational commitment. Indeed, countless studies $[9,50,59]$ have found a positive association between stakeholder orientation and financial performance. In this regard, Maignan et al. [8], based on Homburg and Pflesser's [48] 
research, distinguish between financial and market performance. Other investigations $[8,60]$ have found that stakeholder orientation is positively related to a good reputation.

On the basis of the above, this study focuses on the analysis of stakeholder-oriented behavior through its two components, that is, organizational culture and organizational behavior, as well as its effects on sustainable company performance. In this regard, the present investigation aims to demonstrate that sustainable organizations managed according to stakeholder orientation criteria, as well as the implementation of sustainability efforts on a wide range of their stakeholders, exert effects on financial and market performance, reputation, and organizational commitment.

In order to achieve this aim, this investigation tests two integrating conceptual models according to Maignan et al.'s [8] proposal. The first, the Stakeholder Orientation Model (SO model), estimates the causal relationships among constructs associated with organizational culture, and its effects on stakeholder-oriented behavior. Specifically, this model attempts to test the influence of ethical values on the other two organizational culture components (norms and artifacts) and, in turn, the effect that such norms and artifacts exert on stakeholder-oriented behavior. The second model, the Performance model (P model), estimates the association between stakeholder-oriented behavior and business performance, such as financial and market performance, reputation, and organizational commitment.

In addition, despite the increasing interest in stakeholder management, most investigations that relate stakeholder orientation to organizational performance utilize secondary data, and very few employ primary data [9]. In this regard, both models in this research have been estimated from primary data. The investigation sample comprises large- and medium-sized Colombian companies pertaining to diverse sectors and all of them are involved in business sustainability practices. Both conceptual models were estimated through Structural Equation Modelling (SEM) with the IBM SPSS 19.0 AMOS software (Chicago, IL, USA).

Although numerous empirical investigations within the market-oriented behavior stream $[7,25,26,29,38,40,55,61]$ have focused on customers and competitors, testing models which support the impact of market-oriented behavior on company performance, these investigations have not generally considered stakeholder-oriented behavior, which encompasses wider stakeholder groups [9]. In this vein, our study contributes to the growing body of literature investigating sustainable business, due to both important research and managerial implications stemming from the findings. Our results extend our knowledge on the direct association between business sustainability efforts and organizational performance. In consequence, our outcomes confirm that implementing stakeholder-oriented plans enhances sustainable business performance.

Thus, the present article makes a two-fold relevant contribution, enhancing the body of literature on sustainable business. On the one hand, research has been conducted through primary data from Colombian companies involved in business sustainability practices. On the other hand, our outcomes extend the scarce literature on stakeholder theory, contributing new findings on the association between stakeholder-oriented behavior and organizational performance.

The paper proceeds as follows. In the first section, we review prior literature in order to frame the conceptual underpinnings of the two stakeholder-oriented organizational behavior components, namely organizational culture and organizational behavior; and their impact on organizational performance, assessed through financial and market performance, organizational reputation, and organizational commitment. The second section focuses on methodological issues concerning the research design, sample identification, and analytical instruments. The following section presents the empirical findings and the discussion on both the research and managerial implications. The final section contains our concluding remarks, along with the limitations and suggestions for further research. 


\section{Literature Review}

\subsection{Stakeholder-Oriented Organizational Behavior}

\subsubsection{Organizational Culture}

Organizational culture incorporates aspects from market orientation, stakeholder orientation, and learning orientation. Indeed, CSR implementation requires promoting a new organizational culture, through new-shared values and beliefs, and new behavioral norms, in such a way that expected behavior in the organization contributes to the satisfaction of stakeholder needs. In this regard, organizational culture should incorporate appropriate aspects from market orientation, stakeholder orientation, and learning orientation. These three orientations are considered as components of organizational culture $[29,32]$. The former orientation refers to fostering the interests of consumers and competitors, because of their importance for marketplace strategies. The stakeholder orientation drives changes in organizational culture towards promoting behaviors oriented towards a broader stakeholder range than market orientation. By contrast, the latter orientation refers to fostering an active learning organizational culture, in order to maintain continuous learning on environmental changes related to stakeholder needs [32].

Countless researchers have focused on organizational culture since the 80's [62-64]. For Deshpandé and Webster [65], culture is a "... pattern of shared values and beliefs that help members of an organization understand why things happen and thus teach them the behavioral norms in the organization." (p. 4). Along the same lines, Schein [64] (p. 17) posits that organizational culture is "a pattern of shared basic assumptions that was learned by a group as it solved its problems of external adaptation and internal integration, that has worked well enough to be considered valid and, therefore, to be taught to new members as the correct way to perceive, think and feel in relation to those problems." Similarly, George and Jones [66] (p. 502) point out that organizational culture "is a set of shared values, beliefs and norms that affect the way employees think, feel and behave towards each other and towards those who are outside the organization". Furthermore, Schein [64,67] and Homburg and Pflesser [48] add to norms and values, as well as to artifacts, as another component of the organizational culture. In summary, organizational culture comprises three components, including shared basic values, behavioral norms, and different types of tools (artifacts) for underpinning values and norms, which encourage stakeholder-oriented behavior. Whatever the case, organizational culture, as a set of habits, norms, and beliefs shared by the organization members, enhances the mutual understanding and agreement of common procedures and practices, contributing to achieving organizational goals [68].

For Homburg and Pflesser [48] and Maignan et al. [8], values are systems of beliefs that guide human behavior and generate a common atmosphere organization-wide. Maignan et al. [8] point out that the unique values which contribute to stakeholder orientation are ethical values, team orientation, and openness of internal communication. Ethical values should guide behavior and thinking organization-wide [8]. For Carroll [69], ethical responsibilities in the context of stakeholder-oriented sustainable business "embody those standards, norms, or expectations that reflect a concern for what consumers, employees, shareholders, and the community regard as fair, just, or in keeping with the respect or protection of stakeholders' moral rights" (p. 41). Ford and Richardson [70] argue that ethical behaviors depend on both personal variables and contextual factors, which determine the decision-making and actions of individuals. In this vein, Ford and Richardson [70] stress that beliefs or a person's peers may affect individual behavior. Thereby, the greater number of interactions with these peers, the higher the influence of these peers on their own ethical behavior. Meanwhile, team orientation involves organization members in both supporting and collaboration behavior company-wide [8]. Finally, the openness of internal communication is reflected in social interaction through messages of various kinds [71,72]. Kalla [73] posits that an integrated vision of internal communication facilitates a balanced understanding of employees, who receive information 
from several sources. Communication plays a crucial role in the organizational culture, given that it guides stakeholder actions [48]. Argenti and Forman [74] and Tourish and Hargie [72] demonstrated that companies with effective communication strategies obtain a higher performance.

Meanwhile, norms are established on the basis of desirable behaviors, meaning legitimate specific behaviors. Therefore, norms are related to expected behavior or expected results from such behavior, being shared by a social group $[48,75]$. Consequently, norms operate as guiding principles, such as policies and procedures, including guidelines on working practices, and should be consistent with common values $[48,76]$. Norms are developed from shared values within the organization [48], constituting one of the dominant values within the organizational culture [68]. The effective implementation of norms, as rules which guide the organization strategy, depend on them being understood and accepted by organizational members [48]. Therefore, we propose the following hypothesis:

Hypothesis 1. Shared basic values positively affect behavioral norms.

Finally, artifacts for the diffusion of the values and norms are the most visible part of organizational culture, being tools which facilitate the transmission of values and norms [67] among organizational members. Artifacts have a strong symbolic meaning [48,64,77]. Smircich [78] states that value transmission within the organization is conveyed through myths, stories, legends, and specialized language. In this context, Homburg and Pflesser [48] identify four artifact categories related to stories, arrangements, rituals, and languages [77,79]. For Hatch [80], Homburg and Pflesser [48], and Maignan et al. [8], these artifacts consist of stories, rituals, languages, ceremonies, and physical settings. Whilst values have a wide scope, that of norms and artifacts is limited to only a single stakeholder group [8].

Maignan et al. [8] find that both behavioral norms and artifacts are developed from shared organizational values. These same results were already found by Homburg and Pflesser [48] in a similar investigation focused on market-oriented business. Unlike Homburg and Pflesser [48], Maignan et al.'s [8] investigation, according to the stakeholder orientation approach, focuses on a broader range of stakeholders, considering six stakeholder groups, namely customers, employees, shareholders, suppliers, regulators, and communities. Therefore, we propose the following hypothesis:

Hypothesis 2. Shared basic values positively affect artifacts.

Finally, Maignan et al. [8] likewise demonstrated that norms also exert effects on stakeholder-oriented artifacts. Therefore, we propose the following hypothesis:

\section{Hypothesis 3. Behavioral norms positively affect artifacts.}

\subsubsection{Organizational Behavior}

Organizational behavior is related to organizational members' modus operandi, individually or in groups, within their different roles $[81,82]$. This way of acting results from relationships among both individuals and groups, interaction with the environment, and behavior in the face of change [81,82].

A stakeholder orientation bridges the gap between conventional business theories on both ethics and responsible business behavior. Including environmental and social concerns in the business strategy requires considering all stakeholders and their interactions. Consequently, stakeholder-oriented behaviors are actions which help resolve stakeholder concerns. These actions encompass information collection on stakeholder issues (intelligence generation), the transmission of this information company-wide (intelligence dissemination), and both designing and implementing strategies in order to solve diverse stakeholder expectations arising from this information (responsiveness) [8,25,38,39,61]. 
Intelligence generation consists of identifying critical stakeholders and their concerns, and assessing the extent of organizational influence in resolving these concerns. The dissemination of this stakeholder intelligence is needed to ensure that all organizational members are informed about these issues and can contribute to resolving them [8]. For this purpose, stakeholder intelligence should be transmitted thought both formal and informal communication channels, both vertically and horizontally [58]. Finally, responsiveness to stakeholder intelligence is encouraged through envisioning actions that improve the positive impacts on stakeholders and reduce the negative ones [8].

Since norms prescribe appropriate behavior towards achieving aims [83], they may be predictors of organizational behavior. Furthermore, as norms are stakeholder-specific, they may have effects on stakeholder-oriented organizational behavior [8]. Similar results have been found by Homburg and Pflesser [48] when analyzing the association between norms and market-oriented behavior. Therefore, we propose the following hypothesis:

Hypothesis 4. Behavioral norms positively affect stakeholders-oriented organizational behavior.

Equally, given their symbolic nature, artifacts may motivate and trigger commitment, as well as guide general behavior [38,78]. Treviño et al. [84] found that an ethical organizational environment is directly and positively related to work attitudes. Rego et al. [85] emphasize that employees develop favorable behavior toward many companies with an ethical organizational environment. Accordingly, many studies $[8,26,40,48,57,86]$ have found a positive association between artifacts and stakeholders-oriented organizational behavior. As indicated, it may be that, unlike values, norms and artifacts exert positive effects on stakeholder-oriented organizational behavior. Then, although some investigations $[87,88]$ reveal that the means of diffusion of values and norms, that is, artifacts, do not ensure organizational acceptance, most literature reviews propose the following, which we express as a hypothesis:

\section{Hypothesis 5. Artifacts positively affect stakeholders-oriented organizational behavior.}

\subsection{Impacts of Stakeholder-Oriented Behavior on Organizational Performance}

Empirical findings from investigations at the heart of the market-oriented behavior stream $[26,38,40,61]$ have tested models which support the impact of market-oriented behavior on company performance. In this regard, Kohli and Jaworski $[38,58]$ found a positive association between market-oriented behavior and profitability, overall profits, sales volume, market share, and sales growth. In addition, Kohli and Jaworski $[38,58]$ argued that market-oriented companies impact positively on their human resources, enhancing the team spirit, employee satisfaction with the firm, and organizational commitment. Furthermore, these authors also found that market-oriented behavior is positively related to both customer satisfaction and loyalty. Not all of these relationships between market-oriented behavior and firm performance are affected by environmental factors [38], such as rapid technological change and competitive intensity [58].

These investigations, which focused on customers and competitors, have expanded their focus to encompass broader stakeholder groups, also analyzing their impact on company strategic position $[7,25,29,55]$. Nevertheless, these studies, which link stakeholder-oriented behavior with company performance, are scarce. In this vein, Patel et al. [9] argue that the results from these stakeholder-oriented behavioral investigations should be potentially similar to the findings from market-oriented behavioral studies; that is, stakeholder-oriented behavior explains company performance regarding financial and market performance, reputation, and employee commitment [8].

\subsubsection{Market and Financial Performance}

Previous studies that focused on customers and competitors confirmed the positive association between market orientation and financial performance [26,29,37-40,58,89-91]. Accordingly, Narver and 
Slater [26] found market orientation to play a crucial role as a predictor of profitability, as either return on investment (ROI) or return on assets (ROA) for consumer and industrial companies. It should be noted that Narver and Slater [90] demonstrated that this positive association between market orientation and ROI only occurs for companies with prospector and analyzer strategies, but not with reactor strategy. In this case, it moves to a negative relationship.

The same results have also been presented within the growing body of literature related to stakeholder-oriented behavior, in which investigations also include a wider range of stakeholders for analyzing the positive effect of stakeholder orientation on financial performance $[8,55,59,92]$. In this regard, Berman et al. [93] posit that stakeholder management enhances the generation of income and profits, and consequently, return on investment for shareholders. Likewise, Choi and Wang [94] stress that good relationships with stakeholders contribute to achieving a high performance that persists over time. Thus, the interests of the company in terms of stakeholder relationships depend on value generation for financial success achieved from these relationships [15,93]. Consequently, good stakeholder relationships are valuable, rare, inimitable non-substitutable resources which contribute to companies, helping them to both remain and enhance their competitive advantage and, in consequence, their performance $[54,95]$. Thus, the literature review suggests the following hypothesis:

\section{Hypothesis 6. Stakeholders-oriented organizational behavior positively affects financial performance.}

Furthermore, Slater and Narver [40] demonstrated that market orientation also has a positive effect on ROA, sales growth, and new product success in different business units of the wooden industry. In this regard, Homburg and Pflesser [48] and Maignan et al. [8] also confirm the relationship between stakeholder orientation and market performance. Therefore, we propose the following hypothesis:

Hypothesis 7. Stakeholder-oriented organizational behavior positively affects market performance.

Additionally, Homburg and Pflesser [48] found that, in turn, market performance is an antecedent of financial performance. Thus, we propose:

\section{Hypothesis 8. Market performance positively affects financial performance.}

Panwar et al. [96] point out that company motivations for implementing CSR are firm-size dependent. These authors argue that pressure on financial performance is stronger for large- and medium-sized companies than for small ones. This difference is explained by the fact that the smallest companies are often family owned and are more engaged in social issues relating to their surrounding communities. In addition, these differences are accentuated by the different availability of resources for social actions when comparing large and small companies. In this regard, on the one hand, Panwar et al. [96] consider that small firms are motivated by perceived, potential, and intangible benefits from their CSR efforts, in a non-instrumental way, regarding their close community connections. On the other hand, these authors posit that large companies implement sustainability actions motived by the above benefits, and guided by rational behavior aimed at enhancing the financial performance.

Although Panwar et al.'s [96] contributions distinguish between CSR efforts and motivations according to company size, their findings nevertheless do not negate that, regardless of motivation, CSR efforts have financial performance effects. For this reason, and according to the majority of research in this sphere, we propose a positive association between stakeholder-oriented behavior and financial performance, regardless of size.

Conversely, Duesing [92] found no statistically significant link between stakeholder-orientated behaviors and financial performance. Likewise, several investigations on market orientation [97] found no statistically significant relationship between market-orientated behaviors and financial performance. Despite these rare findings, the literature review generally supports the previous hypotheses. 


\subsubsection{Organizational Reputation}

Organization reputation stems from organizational capacity to generate valuable results for diverse stakeholders [56]. Accordingly, this organizational reputation is based upon both internal and external stakeholder intervention [30]. In fact, reputation is a measurement of company position, both internally with its employees, and externally with the other stakeholders [56]. In this vein, for Fombrun [98] and Fombrun and Van Riel [56], organizational reputation is the stakeholders' immediate mental image, evolved from past company actions and their effects, due to effective communication efforts carried out by the firm.

Organizational reputation is the company assessment by stakeholders over time [98,99]. Therefore, business reputation is a dynamic factor which is slowly accumulated [98]. Hall [100] posits that building up reputation requires many years, during which numerous independent factors converge, subject to unique, unrepeatable historical circumstances.

Organizational reputation influences stakeholder behavior towards the company. In this vein, Fombrun, Ponzi and Newburry [101] posit that organizational reputation influences stakeholder supportive relationships and their participation in company activities. Thus, given that organizational reputation is developed from stakeholder interactions, both stakeholder relationship management and public confidence generation play a crucial role in reputation management [102]. Consequently, knowing and analyzing information which influences company stakeholder perceptions improves stakeholder emotional reaction prediction related to the firm [101]. Thereby, a company can more effectively manage its reputation and its influence on stakeholder behavior towards the firm. In this regard, stakeholder-oriented behaviors enable the company to develop and maintain stakeholder relationships based on mutual trust and cooperation which, in turn, contribute to building reputation and brand value $[20,45,95]$.

Organizational culture, as a component of stakeholder-oriented behavior, leads to appropriate stakeholder interaction strategies [56], which contribute to building the desired image of the company in the minds of the stakeholders. Companies with a strong, consistent organizational culture are prone to be involved in systematic efforts at influencing stakeholder perceptions [56]. Indeed, since organizational culture encourages members to develop stakeholder-oriented behaviors, it is thus more likely that this behavior will foster favorable stakeholder perceptions and, in this manner, organizational reputation is shaped. In this regard, Maignan et al. [8], based on Fombrun et al.'s [60] postulates, demonstrate that stakeholder-orientated behavior is positively related to organizational reputation. Therefore, the following hypothesis is proposed:

Hypothesis 9. Stakeholders-oriented organizational behavior positively affects organizational reputation.

Reputation is a scarce, valuable, inimitable, and irreplaceable resource and, in consequence, a source of advantage competitive with a capacity for generating enterprise rents [30]. Fombrun and Shanley [103] posit that organizational reputation enhances value generation, providing at least three competitive advantages, namely, cost reduction, increase prices, and creating barriers to competition. Furthermore, numerous authors $[100,103,104]$ highlight that both products and company reputation have an important strategic value, because they are the most valuable source of sustainable competitive advantage for companies with differentiation strategies.

Based on the above, Schwaiger [105] and Schwaiger et al. [106] found that reputation affects market performance, through building trust and loyalty and, furthermore, has a positive association with the client retention rate $[105,107]$. Therefore, the following hypothesis is proposed:

Hypothesis 10. Organizational reputation positively affects market performance. 


\subsubsection{Organizational Commitment}

Organizational commitment is related to employee identification and participation with the organization and its goals, their desire to remain organizational members, and their willingness to offer the greatest effort to the organization [108]. For Mowday et al. [108], organizational commitment arises as a belief in and acceptation of organizational values and goals.

Meyer and Allen [109] identify three components of organizational commitment, based on the different types of employee relationship with the organization. Meyer and Allen's [109] three-component model identifies affective, normative, and continuance commitment $[109,110]$. Other investigations also include as commitment components both voice behaviors [111] and antisocial behaviors [112].

Affective commitment refers to a sense of employee emotional attachment to the organization [113] as a result of having established an affective relationship and a high level of identification toward the company $[109,110]$. Normative commitment refers to a sense of loyalty based on employees' perceived obligation toward the organization [113] due to social norms, their moral sense, or their gratitude for benefits received $[109,110]$. Finally, continuance commitment refers to employees' sense of organizational membership, after comparing the costs of remaining at the company regarding what they stand to lose if leaving $[109,114]$. In turn, continuance commitment consists of two dimensions, meaning, perceived sacrifice and few alternative employment opportunities $[109,115]$. Meyer and Allen's [109] model identifies continuance commitment as perceived sacrifice commitment, that is, employees' sense that organizational membership provides valuable benefits [113], compared to other employment options. By contrast, voice behaviors refer to providing constructive suggestions in order to enhance organizational efficiency through improving work procedures [111,116]. Antisocial behaviors refer to those employee behaviors that damage the organization or harm other members [112].

On the basis of the above, organizational commitment is related to motives which drive employee behavior toward organizational goals [113]. In this regard, organizational culture affects organizational members' behavior [57] and, in consequence, fosters organizational commitment [117]. Since stakeholder-oriented organizational behavior is formed through conduct which meets stakeholder expectations [26,38], it is likely that stakeholder orientation fosters the bond between employees and organization, that is, organizational commitment. In this vein, Kohli and Jaworski [38] stress that as organizational commitment increases, stakeholder orientation develops a sense of pride in employees, of belonging to a company, in which all organizational members are willing to work together in order to achieve the organizational goals.

As indicated, many studies $[26,38,61,86]$ have demonstrated that stakeholder orientation is positively related to organizational commitment, fostering a bond between employees and the company. In this regard, Themba and Marandu [118] point out, in addition, that stakeholder orientation triggers an employee affective sense towards the organization, so that they are willing to make personal sacrifices in order to achieve organizational goals. Although Powpaka [119] also found a positive relationship between stakeholder-oriented behavior and organizational commitment, this association was weak. Therefore, the following hypothesis is proposed:

Hypothesis 11. Stakeholder-oriented organizational behavior positively affects organizational commitment.

In turn, organizational commitment and reputation are positively linked [101], because satisfied employees feel a stronger commitment to the company, contributing to improving the company image with respect to stakeholders. In this regard, Helm [102] also highlights the crucial role played by employees in the reputation-building process. According to Lau and Lin [120], internal processes, culture, and human resources contribute to maintaining and improving brand externally.

On one hand, the signals perceived by stakeholders regarding company behavior towards their employees trigger confidence and respect among stakeholders, contributing to generate favorable 
organizational reputation [101]. On the other hand, organizational reputation thrives on the appropriate quality of interactions between employees and company clients [102,121]. In turn, employees are affected by other stakeholder perceptions of the company, thereby entailing a bilateral relationship between organizational reputation and employees [102]. Therefore, the following hypothesis is proposed:

Hypothesis 12. Organizational commitment positively affects organizational reputation.

\section{Methodology}

\subsection{Proposed Model}

This paper tests a structural model in which the central latent variable is stakeholder-oriented behavior (Figure 1), according to Maignan et al.'s [8] research. Accordingly, this study attempts to estimate, on the one hand, causal relationships of antecedent factors of stakeholder-oriented behavior and, on the other hand, the effects of this behavior on a set of variables which assesses business performance.

Due to the global conceptual model being related to antecedents and consequences of stakeholder-oriented behavior, the global model is divided into two sub-models. One of them, named the stakeholder orientation model (SO model), is used for testing the relationships among predictor variables of stakeholder-oriented behavior. The second sub-model, the performance model (P model), estimates the causal relationships among stakeholder-oriented behavior and dependent variables of this construct, in order to determine whether contrast business performance is affected by socially responsible behavior. The estimation of these two sub-models enables testing twelve hypotheses derived from the literature review.

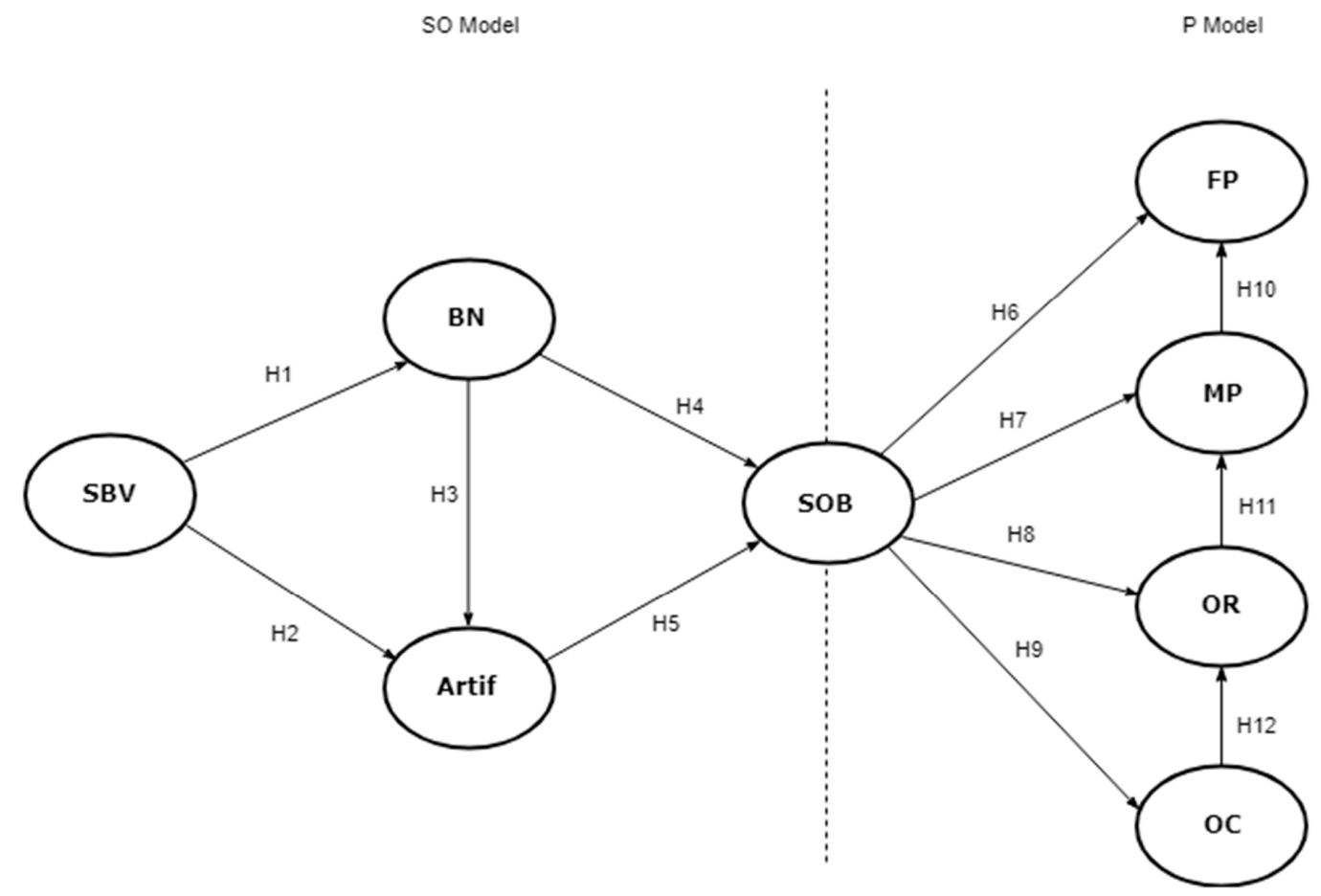

Figure 1. Investigation model.

\subsection{Participants and Procedure}

A structured questionnaire survey method was used in this investigation. The questionnaire was structured according to the literature review and items from tested and confirmed scales of constructs related to the conceptual model. The questionnaire was distributed among large, medium, and small 
Colombian enterprises belonging to different sectors. All participant companies in the data collection were preselected based on the condition of regularly implementing RSC efforts, regardless of the motivations which had fostered this behavior. From the 458 returned questionnaires, only 279 were considered as valid for statistical analysis. The sample data collected in this research, as shown in Table 1 , indicates that there is a broad spectrum of business represented in this study. The random sample used in this investigation matches the distribution of the total population consisting of different company sizes, which regularly implement RSC efforts, and the activity sector.

Table 1. Characteristics of the sample.

\begin{tabular}{cccc}
\hline Size & $\mathbf{\%}$ & Sector & $\%$ \\
\hline Large & $104(37.28 \%)$ & Manufacturing & $86(30.82 \%)$ \\
Medium & $100(35.84 \%)$ & Services & $79(28.32 \%)$ \\
Small & $75(26.88 \%)$ & Commerce & $76(27.24 \%)$ \\
& & Farming & $19(6.8 \%)$ \\
& & Construction & $18(6.45 \%)$ \\
Total & 279 & Miner & $1(0.36 \%)$ \\
& & Total & 279 \\
\hline
\end{tabular}

A confirmatory factor analysis and structural equation modelling were performed to test the measurement model and to assess the structural relationships of the constructs in the conceptual model. This statistical method is appropriate for analyzing causal processes that generate observations of multiple variables [122]. This analysis was performed using SPSS/AMOS 19.0 software.

\subsection{Instruments}

Scales used in this study are adaptations from previous studies (Table 2). Thus, the SO model estimation is based on research from Homburg and Pflesser [48] and Maignan et al. [8]. According to these investigations, the main stakeholder-oriented behavior construct's antecedents are behavioral norms and artifacts. In turn, shared basic values are antecedents of behavioral norms and artifacts. All items related to the SO model were measured using a seven-point Likert-type scale ranging from 1 (strongly disagree) to 7 (strongly agree).

Stakeholder-oriented behavior (SOB) was measured using the 12-item Maignan et al. [8] scale, which is largely based on Maignan and Ferrel [25], who in turn, according to Kohli and Jaworski [38] and Jaworski and Kohli [61], included three kinds of stakeholder-oriented behaviors, namely, intelligence generation (IG), intelligence dissemination (ID), and responsiveness (RE). The following are some of the items included: "Our organization generates information about our image for this stakeholder group at least once a year" (IG); "This stakeholder group's concerns are disclosure by means of regular documents (v.gr., reports, bulletins) distributed organization-wide" (ID); or "We quickly adapt our practices accordingly to this stakeholder group's suggestions" (RE). These items are assessed for each stakeholder group (clients, suppliers, employees, public administrations, community, and shareholders). 
Table 2. Scales used in the conceptual model.

\begin{tabular}{|c|c|c|c|}
\hline Construct & Description & Items & Scale \\
\hline $\begin{array}{l}\text { Stakeholder-oriented } \\
\text { behaviors (SOB) }\end{array}$ & $\begin{array}{l}\text { Three kind of } \\
\text { stakeholder-oriented } \\
\text { behaviors: intelligence } \\
\text { generation (IG), intelligence } \\
\text { dissemination (ID), } \\
\text { and responsiveness (RE) }\end{array}$ & $\begin{array}{l}12 \\
\text { IG-4 items } \\
\text { ID—4 items } \\
\text { RE-4 items }\end{array}$ & $\begin{array}{l}\text { Maignan et al. [5] based on } \\
\text { Maignan and Ferrel [51], } \\
\text { according to Kohli and } \\
\text { Jaworski [27] and Jaworski } \\
\text { and Kohli [50] }\end{array}$ \\
\hline Shared basic values (SBV) & $\begin{array}{l}\text { Second-order } \\
\text { multidimensional construct } \\
\text { consisted of ethical values } \\
\text { (EV), team orientation (TO), } \\
\text { and openness of internal } \\
\text { communications (OIC). }\end{array}$ & $\begin{array}{l}11 \\
\text { EV-4 items } \\
\text { TO-4 items } \\
\text { OIC-3 items }\end{array}$ & Maignan et al. [5] \\
\hline Behavioral norms (BN) & $\begin{array}{l}\text { Related to stakeholder policies } \\
\text { (SP) and procedures (PR) }\end{array}$ & $\begin{array}{l}12 \\
\text { SP-6 items } \\
\text { PR-6 items }\end{array}$ & Maignan et al. [5] \\
\hline Artifacts (Artif) & $\begin{array}{l}\text { Related to stakeholder } \\
\text { strengthening (SS) and } \\
\text { communication with } \\
\text { stakeholders (SC) }\end{array}$ & $\begin{array}{l}12 \\
\text { SS-6 items } \\
\text { SC-6 items }\end{array}$ & Maignan et al. [5] \\
\hline Financial performance (FP) & $\begin{array}{l}\text { Financial performance } \\
\text { evolution during last } \\
\text { three years, in comparison } \\
\text { with competitors }\end{array}$ & 3 & $\begin{array}{l}\text { Maignan et al. [5] adapted } \\
\text { from Homburg and } \\
\text { Pflesser [38] }\end{array}$ \\
\hline Market performance (MP) & $\begin{array}{l}\text { Market share evolution during } \\
\text { last three years, in comparison } \\
\text { with competitors }\end{array}$ & 6 & Homburg and Pflesser [38] \\
\hline $\begin{array}{l}\text { Organizational } \\
\text { reputation (OR) }\end{array}$ & $\begin{array}{l}\text { Confidence in or reliability of } \\
\text { products or services }\end{array}$ & 4 & $\begin{array}{l}\text { Maignan et al. [5] scale, } \\
\text { adapted from Homburg } \\
\text { and Pflesser [38] }\end{array}$ \\
\hline $\begin{array}{l}\text { Organizational } \\
\text { commitment }(\mathrm{OC})\end{array}$ & $\begin{array}{l}\text { Sense of employee pride of } \\
\text { belonging to a company, or } \\
\text { making personal sacrifices in } \\
\text { order to achieve } \\
\text { organizational goals }\end{array}$ & 7 & Jaworski and Kohli [50] \\
\hline
\end{tabular}

Shared basic values (SBV) were measured in this study using a second-order multidimensional construct according to Maignan et al. [8], related to three basic dimensions of this construct, namely, ethical values (EV), team orientation (TO), and openness of internal communication (OIC). Johnson, Rosen, and Chang's [123] process was followed so as to demonstrate the appropriateness and validity of the second-order construct. In total, this construct was measured using 11 items: ethical values: $\mathrm{EV} \_4$ items; team orientation: $\mathrm{TO} \_4$ items; and openness of internal communication: OIC -3 items. The following are some of the items included: "There is a shared value system to support the ethics in our organization" (EV); "In our organization, we aim to put into practice a strong team spirit" (TO); or "we strive to build a high level of information interchange among our organizational units (v. gr., among departments, teams)" (OIC).

Behavioral norms (BN) was measured using the 12-item Maignan et al. [8] scale. Among all of the types of behavioral norms, Homburg and Pflesser [48] include the two most commonly used norms related to stakeholder policies ( $\mathrm{SP}-6$ items) and procedures ( $\mathrm{PR}-6$ items). The following are some of the items included: "Our organization uses well defined policies which specify how employees must act with the clients" (SP) or "Our business policies specify demanding quality norms for all our products and services" (PR). These items are assessed for each stakeholder group (clients, suppliers, employees, public administrations, community, and shareholders).

Artifacts (Artif) was also measured using the 12-item Maignan et al. [8] scale. These authors include two of the most commonly used artifacts related to stakeholder strengthening (SS-6 items) and communication with stakeholders (SC -6 items). The following are some of the items included: 
"Our organization often invites suppliers to attend conferences and special events organized by us" (SS) or "Our website has an area where suppliers can easily interact with our agents" (SC). These items are assessed for each stakeholder group (clients, suppliers, employees, public administrations, community, and shareholders).

Related to the Performance model ( $\mathrm{P}$ model), according to the literature reviewed, stakeholder-oriented behavior explains company performance. The main performance variables used to assess this effect are financial and market performance, reputation, and employee commitment [8].

Financial performance (FP) was measured using a three-item Maignan et al. [8] scale, adapted from Homburg and Pflesser [48]. This scale measures the financial performance evolution during the last three years, in comparison with competitors. Market performance (MP) was measured using a six-item Homburg and Pflesser [48] scale. This scale measures the market share evolution during the last three years, in comparison with competitors, assessing aspects such as client satisfaction or new clients attracted. Organizational reputation (OR) was measured using a four-item Maignan et al. [8] scale, also adapted from Homburg and Pflesser [48]. This scale measures organizational reputation based on issues related to confidence in or the reliability of products or services. Finally, as the organizational commitment (OC) indicator, a seven-item Jaworski and Kohli [61] scale was used, related to the sense of employee pride of belonging to a company, or being willing to make personal sacrifices in order to achieve organizational goals.

\subsection{Common Method Bias}

According to Fuller et al. [124], the design of the study's procedure is one of the ways to control for method bias. Therefore, we undertook a priori and post procedures to minimize common method bias. Accordingly, questionnaire pre-testing before the study was conducted to check the appropriate questionnaire layout. Furthermore, participants were informed that their answers would be anonymous and that they should be open and honest. As previously mentioned, we also used tested scales from previous studies to avoid the potential ambiguity of the items. Additionally, in relation to the order of questions in the questionnaire, the independent variables were located before the dependent ones.

In addition, results from Harman's single-factor test [125] indicate that a single factor explains $51.57 \%$ of the total variance in the SO model and $55.47 \%$ in the P model. Accordingly, the explained variance in each model was around $50 \%$, demonstrating that common method bias is unlikely to affect the results [124], assuming as acceptable the explanatory capacity of the latent variables of the conceptual model.

\section{Results}

\subsection{Measurement Model Analysis}

A preliminary exploratory factor analysis was performed to optimize the scale composition. Our metric pre-testing of the measurement model suggested the elimination of items of some constructs, since either some had a factorial load of less than 0.6 [126] or their omission appreciably increased the Cronbach's alpha. Scales affected and the final number of items are: team orientation (TO-3 items), behavioral norms (BN-9 items), artifacts (Artifact—6 items), market performance (MP—4 items), and organizational commitment (OC-5 items).

Moreover, we performed a confirmatory factor analysis to test the final composition of the measurement model. For this analysis, we used maximum likelihood estimation and the bootstrapping technique to correct any issues stemming from failures of the normality multivariate conditions. In fact, maximum likelihood estimation generates robust statistics in the presence of normality problems [122].

Our testing of the measurement model indicated satisfactory findings, with all indicators being acceptable (Table 3$)$. The convergent validity analysis showed that all indicators loaded onto their respective latent factor significantly $(p<0.001)$ and substantially $(\lambda>0.5)$ [127]. Furthermore, 
the percentages of variance explained were also acceptable $\left(R^{2} \geq 0.5\right)$, even for the dimensions of the second order construct (shared basic values -SBV). Furthermore, the scale's reliability was confirmed. Indeed, the composite reliability index (CRI) and average variance extracted (AVE) exceeded the recommended minimum values of 0.7 and 0.5 , respectively [128].

Table 3. Convergent validity and reliability of measurement model for SO model.

\begin{tabular}{|c|c|c|c|c|c|c|c|}
\hline Variables & Indicator & $\begin{array}{l}\text { Standardized } \\
\text { Loads }\end{array}$ & $t$-Value & $R^{2}$ & Cronbach's Alpha & CRI & AVE \\
\hline \multirow{3}{*}{$\begin{array}{l}\text { Shared basic values } \\
\text { (SBV) (second order) }\end{array}$} & EV & $0.833^{* *}$ & 9.348 & 0.693 & \multirow{3}{*}{-} & \multirow{3}{*}{0.919} & \multirow{3}{*}{0.791} \\
\hline & TO & $0.938 * *$ & 9.938 & 0.879 & & & \\
\hline & OIC & $0.894 * *$ & 11.447 & 0.799 & & & \\
\hline \multirow{4}{*}{ Ethical values (EV) } & EV1 & $0.737^{1}$ & - & 0.543 & \multirow{4}{*}{0.885} & \multirow{4}{*}{0.890} & \multirow{4}{*}{0.700} \\
\hline & EV2 & $0.901 * *$ & 16.121 & 0.812 & & & \\
\hline & EV3 & $0.811^{* *}$ & 13.390 & 0.658 & & & \\
\hline & EV4 & $0.816^{* *}$ & 15.778 & 0.667 & & & \\
\hline \multirow{3}{*}{ Team orientation (TO) } & TO1 & $0.826^{1}$ & - & 0.683 & \multirow{3}{*}{0.879} & \multirow{3}{*}{0.879} & \multirow{3}{*}{0.710} \\
\hline & TO2 & $0.853 * *$ & 22.625 & 0.728 & & & \\
\hline & TO4 & $0.845^{* *}$ & 15.027 & 0.715 & & & \\
\hline \multirow{3}{*}{$\begin{array}{l}\text { Openness of internal } \\
\text { communications (OIC) }\end{array}$} & OIC1 & $0.853^{1}$ & - & 0.728 & \multirow{3}{*}{0.888} & \multirow{3}{*}{0.917} & \multirow{3}{*}{0.790} \\
\hline & OIC2 & $0.908 * *$ & 19.815 & 0.824 & & & \\
\hline & OIC3 & $0.804^{* *}$ & 13.819 & 0.646 & & & \\
\hline \multirow{9}{*}{ Behavioral norms (BN) } & BN_SP_CL & $0.828^{* *}$ & 16.378 & 0.685 & \multirow{9}{*}{0.932} & \multirow{9}{*}{0.928} & \multirow{9}{*}{0.590} \\
\hline & BN_PR_CL & $0.807^{* *}$ & 11.920 & 0.651 & & & \\
\hline & BN_SP_SU & $0.868 * *$ & 14.146 & 0.754 & & & \\
\hline & BN_SP_HR & $0.828^{* *}$ & 11.596 & 0.686 & & & \\
\hline & BN_PR_HR & $0.814^{* *}$ & 11.532 & 0.662 & & & \\
\hline & BN_SP_PA & $0.717^{* *}$ & 8.232 & 0.514 & & & \\
\hline & BN_PR_PA & $0.662 * *$ & 10.231 & 0.438 & & & \\
\hline & BN_PR_CO & $0.706^{* *}$ & 11.319 & 0.498 & & & \\
\hline & BN_PR_SH & $0.665^{* *}$ & 8.093 & 0.442 & & & \\
\hline \multirow{6}{*}{ Artifacts (Artif) } & Artif_CL & $0.781 * *$ & 15.151 & 0.610 & \multirow{6}{*}{0.916} & \multirow{6}{*}{0.923} & \multirow{6}{*}{0.670} \\
\hline & Artif_SU & $0.784^{* *}$ & 15.377 & 0.614 & & & \\
\hline & Artif_HR & $0.843^{* *}$ & 17.250 & 0.710 & & & \\
\hline & Artif_PA & $0.855^{* *}$ & 17.143 & 0.732 & & & \\
\hline & Artif_CO & $0.894^{* *}$ & 17.237 & 0.799 & & & \\
\hline & Artif_SH & $0.733^{* *}$ & 14.824 & 0.538 & & & \\
\hline \multirow{12}{*}{$\begin{array}{l}\text { Stakeholder-oriented } \\
\text { behaviors (SOB) }\end{array}$} & SOB_IG_1 & $0.935 * *$ & 16.354 & 0.875 & & & \\
\hline & SOB_IG_2 & $0.964^{* *}$ & 18.119 & 0.929 & & & \\
\hline & SOB_IG_3 & $0.973^{* *}$ & 23.970 & 0.947 & & & \\
\hline & SOB_IG_4 & $0.949 * *$ & 24.088 & 0.901 & & & \\
\hline & SOB_ID_1 & $0.922 * *$ & 25.182 & 0.851 & & & \\
\hline & SOB_ID_2 & $0.951^{* *}$ & 27.194 & 0.904 & & & \\
\hline & SOB_ID_3 & $0.952 * *$ & 25.938 & 0.906 & 0.989 & 0.990 & 0.890 \\
\hline & SOB_ID_4 & $0.947^{* *}$ & 26.710 & 0.898 & & & \\
\hline & SOB_RE_1 & $0.942 * *$ & 25.258 & 0.887 & & & \\
\hline & SOB_RE_2 & $0.934^{* *}$ & 24.484 & 0.873 & & & \\
\hline & SOB_RE_3 & $0.890 * *$ & 21.314 & 0.792 & & & \\
\hline & SOB_RE_4 & $0.955^{* *}$ & 20.000 & 0.912 & & & \\
\hline
\end{tabular}

Additionally, we compared the AVE with the squared inter-construct correlations to assess whether the model measures separated the constructs effectively [126]. In all cases, the AVE was greater than the squared correlation estimates, providing support for discriminant validity (Table 4).

Table 4. Discriminant validity of measurement model for SO model ${ }^{1}$.

\begin{tabular}{ccccc}
\hline & SBV & BN & Artif & SOB \\
\hline SBV & 0.889 & $0.876 *(40.777)$ & $0.416^{*}(7.597)$ & $0.587 *(13.455)$ \\
BN & $(0.834 ; 0.918)$ & 0.770 & $0.397^{*}(7.319)$ & $0.599 *(14.485)$ \\
Artif & $(0.306 ; 0.526)$ & $(0.289 ; 0.505)$ & 0.817 & $0.734 *(24.159)$ \\
SOB & $(0.499 ; 0.675)$ & $(0.517 ; 0.681)$ & $(0.674 ; 0.794)$ & 0.943
\end{tabular}

${ }^{*} p<0.01 .{ }^{1}$ Above diagonal: estimated correlation between factors and ( $t$-value)/Diagonal: squared root of variance extracted/Below diagonal: confidence interval for correlation between factors. NOTE: SBV = Shared basic values; $\mathrm{BN}=$ Behavioral norms; Artif $=$ Artifacts $; \mathrm{SOB}=$ Stakeholder-oriented behavior. 
The goodness-of-fit indices of the measurement model presented acceptable values (Table 5) [129-134]. It should be pointed out that maximum likelihood estimates are highly sensitive to sample sizes. In the case $\mathrm{N}=279(\mathrm{~N}>200)$, it is thus to be expected that the goodness-of-fit indices tend to be worse [126] and $\chi^{2}$ increases, making it highly probable that it will be significant (type I error). Consequently, the goodness-of-fit indices were analyzed together with other fit indices $[131,133,135]$.

Table 5. Fit results for structural equation model of SO model.

\begin{tabular}{cccccccc}
\hline$\chi 2$ (df); $p$-Value & $\chi^{2 / d f}$ & CFI & TLI & NFI & RMSEA & GFI & AGFI \\
\hline $\begin{array}{c}\text { 1392.166 (591); } \\
0.000\end{array}$ & 2.356 & 0.94 & 0.932 & 0.901 & 0.070 & 0.782 & 0.74 \\
\hline
\end{tabular}

Consequently, we conclude that the measurement model regarding the SO model tested indicates a satisfactory validity and reliability, and an acceptable goodness-of-fit. In turn, the same results hold for the P model. As shown in Table 6, both the convergent validity and scale reliability have been supported.

Table 6. Convergent validity and reliability of measurement model for P model.

\begin{tabular}{|c|c|c|c|c|c|c|c|}
\hline Variables & Indicator & $\begin{array}{l}\text { Standardized } \\
\text { Loads }\end{array}$ & $t$-Value & $R^{2}$ & Cronbach's Alpha & CRI & AVE \\
\hline \multirow{3}{*}{$\begin{array}{c}\text { Financial } \\
\text { performance (FP) }\end{array}$} & FP1 & $0.941 *$ & 20.860 & 0.886 & \multirow{3}{*}{0.958} & \multirow{3}{*}{0.957} & \multirow{3}{*}{0.880} \\
\hline & FP2 & $0.933 *$ & 20.690 & 0.870 & & & \\
\hline & FP3 & $0.946^{*}$ & 21.093 & 0.894 & & & \\
\hline \multirow{4}{*}{$\begin{array}{c}\text { Market } \\
\text { performance (MP) }\end{array}$} & MP1 & 0.954 * & 19.214 & 0.909 & \multirow{4}{*}{0.909} & \multirow{4}{*}{0.926} & \multirow{4}{*}{0.80} \\
\hline & MP 2 & 0.934 * & 20.872 & 0.872 & & & \\
\hline & MP 3 & $0.852 *$ & 18.442 & 0.726 & & & \\
\hline & $\mathrm{MP} 4$ & $0.729 *$ & 14.580 & 0.532 & & & \\
\hline \multirow{4}{*}{$\begin{array}{l}\text { Organizational } \\
\text { reputation }(\mathrm{OR})\end{array}$} & OR1 & $0.935^{*}$ & 18.333 & 0.874 & \multirow{4}{*}{0.966} & \multirow{4}{*}{0.977} & \multirow{4}{*}{0.914} \\
\hline & OR 2 & $0.951 *$ & 14.178 & 0.904 & & & \\
\hline & OR 3 & $0.944^{*}$ & 14.200 & 0.892 & & & \\
\hline & OR4 & $0.916^{*}$ & 13.354 & 0.839 & & & \\
\hline \multirow{5}{*}{$\begin{array}{l}\text { Organizational } \\
\text { commitment (OC) }\end{array}$} & OC1 & $0.747^{*}$ & 15.909 & 0.558 & \multirow{5}{*}{0.909} & \multirow{5}{*}{0.904} & \multirow{5}{*}{0.66} \\
\hline & OC2 & $0.750 *$ & 13.462 & 0.563 & & & \\
\hline & OC4 & $0.915^{*}$ & 14.000 & 0.837 & & & \\
\hline & OC5 & $0.761 *$ & 15.302 & 0.579 & & & \\
\hline & OC7 & $0.860 *$ & 15.122 & 0.739 & & & \\
\hline \multirow{12}{*}{$\begin{array}{c}\text { Stakeholder-oriented } \\
\text { behaviors (SOB) }\end{array}$} & SOB_IG_1 & $0.898^{*}$ & 15.667 & 0.806 & \multirow{12}{*}{0.989} & \multirow{12}{*}{0.987} & \multirow{12}{*}{0.864} \\
\hline & SOB_IG_2 & $0.938 *$ & 19.500 & 0.879 & & & \\
\hline & SOB_IG_3 & 0.928 * & 20.972 & 0.862 & & & \\
\hline & SOB_IG_4 & 0.897 * & 20.342 & 0.804 & & & \\
\hline & SOB_ID_1 & 0.864 * & 19.487 & 0.746 & & & \\
\hline & SOB_ID_2 & $0.905^{*}$ & 18.250 & 0.818 & & & \\
\hline & SOB_ID_3 & 0.927 * & 20.711 & 0.859 & & & \\
\hline & SOB_ID_4 & 0.899 * & 20.179 & 0.809 & & & \\
\hline & SOB_RE_1 & 0.987 * & 21.051 & 0.975 & & & \\
\hline & SOB_RE_2 & 0.966 * & 23.114 & 0.934 & & & \\
\hline & SOB_RE_3 & 0.954 * & 20.125 & 0.911 & & & \\
\hline & SOB_RE_4 & 0.983 * & 18.860 & 0.966 & & & \\
\hline
\end{tabular}

Furthermore, discriminant validity has also been demonstrated according to a comparison between AVE and the squared inter-construct correlations [126] (Table 7). 
Table 7. Discriminant validity of measurement model for $\mathrm{P}$ model ${ }^{1}$.

\begin{tabular}{cccccc}
\hline & FP & MP & OR & OC & SOB \\
\hline FP & 0.940 & $0.592 *(14.214)$ & $0.361 *(6.845)$ & $0.382 *(7.149)$ & $0.270 *(4.897)$ \\
MP & $(0.508 ; 0.676)$ & 0.872 & $0.631 *(16.335)$ & $0.605 *(14.295)$ & $0.527 *(11.692)$ \\
OR & $(0.255 ; 0.467)$ & $(0.553 ; 0.709)$ & 0.956 & $0.708 *(21.015)$ & $0.469 *(9.763)$ \\
OC & $(0.276 ; 0.488)$ & $(0.521 ; 0.689)$ & $(0.640 ; 0.776)$ & 0.810 & $0.610 *(15.048)$ \\
SOB & $(0.160 ; 0.380)$ & $(0.437 ; 0.617)$ & $(0.373 ; 0.565)$ & $(0.528 ; 0.692)$ & 0.930 \\
\hline
\end{tabular}

${ }^{*} p<0.01 .{ }^{1}$ Above diagonal: estimated correlation between factors and ( $t$-value)/Diagonal: squared root of variance extracted/Below diagonal: confidence interval for correlation between factors. NOTE: FP = Financial performance; $\mathrm{MP}=$ Market performance; $\mathrm{OR}=$ Organizational reputation; $\mathrm{OC}=$ Organizational commitment; $\mathrm{SOB}=$ Stakeholder-oriented behavior.

Finally, as shown in Table 8, the goodness-of-fit indices of the measurement model also presented acceptable values [129-134].

Table 8. Fit results for structural equation model of P model.

\begin{tabular}{cccccccc}
\hline$\chi 2$ (df); $\boldsymbol{p}$-Value & $\chi \mathbf{2}$ /df & CFI & TLI & NFI & RMSEA & GFI & AGFI \\
\hline $933.068(317) ; 0.000$ & 2.943 & 0.951 & 0.942 & 0.928 & 0.084 & 0.798 & 0.742 \\
\hline
\end{tabular}

\subsection{Structural Model Analysis}

The structural SO model shown in Figure 1 was also tested. Given that sample size used in this study $(\mathrm{N}>200)$ penalizes the model fit, the combined analysis using different types of goodness-of-fit indices [135] revealed that the structural model achieved an acceptable fit level (see Table 9). The structural paths between shared basic values and behavioral norms $(\beta=0.878$, $p<0.001)$, behavioral norms and stakeholder-oriented behavior $(\beta=0.374, p<0.001)$, and artifacts and stakeholder-oriented behavior $(\beta=0.580, p<0.001)$, were significant, thus confirming $\mathrm{H} 1, \mathrm{H} 4$, and H5, respectively. Conversely, the structural path between shared basic values and artifacts $(\beta=-0.293$, n.s. $)$, and behavioral norms and artifacts $(\beta=0.139$, n.s.), were not significant, suggesting that both shared basic values and behavioral norms have no direct effect on the artifacts. Thus, H2 and H3 were not supported.

Table 9. Fit results and path coefficients for structural equation models (SO model).

\begin{tabular}{|c|c|c|c|c|}
\hline Hypothesis No. & Structural Relationship & $\begin{array}{l}\text { Standardized } \\
\text { Coefficients }\end{array}$ & Robust $t$-Value & Conclusion \\
\hline H1 & SBV-BN & $0.878^{*}$ & 10.590 & Accepted \\
\hline H2 & SBV-Artif & 0.293 & 1.301 & Not Accepted \\
\hline $\mathrm{H} 3$ & BN-Artif & 0.139 & 0.664 & Not Accepted \\
\hline $\mathrm{H} 4$ & BN-SOB & 0.374 * & 8.745 & Accepted \\
\hline H5 & Artif-SOB & 0.580 * & 11.469 & Accepted \\
\hline \multicolumn{5}{|c|}{ Fit Results } \\
\hline$\chi^{2(d f) ; p \text {-Value }}$ & $x^{2 / d f}$ & TLI & RMSEA & RMR \\
\hline $\begin{array}{c}1380.812(591) \\
0.000\end{array}$ & 2.336 & 0.933 & 0.069 & 0.037 \\
\hline
\end{tabular}

Furthermore, the goodness-of-fit indices achieved from estimating the P model revealed that the structural model has a satisfactory fit level: $\chi 2(\mathrm{df})=954.10(319), p<0.001, \mathrm{NFI}=0.93, \mathrm{RMSEA}=0.08$, $\mathrm{TLI}=0.94, \mathrm{CFI}=0.95, \chi 2 / \mathrm{df}=2.991$, taking into account the issues arising from a sample size over 200 [135]. The structural paths between stakeholder-oriented behavior and market performance $(\beta=0.304, p<0.001)$, stakeholder-oriented behavior and organizational commitment $(\beta=0.610$, $p<0.001)$, market performance and financial performance $(\beta=0.648, p<0.001)$, organizational reputation and market performance $(\beta=0.489, p<0.001)$, and organizational commitment and organizational reputation $(\beta=0.673, p<0.001)$, were significant, thus confirming H7, H9, H10, 
H11, and H12, respectively. However, the structural path between stakeholder-oriented behavior and financial performance ( $\beta=-0.055$, n.s.), and stakeholder-oriented behavior and organizational reputation ( $\beta=0.066$, n.s.), was not significant, suggesting that stakeholder-oriented behavior does not have a direct effect on either financial performance and organizational reputation. Thus, $\mathrm{H7}$ and H8 were not supported, respectively (Table 10).

Table 10. Fit results and path coefficients for structural equation models (SO model).

\begin{tabular}{|c|c|c|c|c|}
\hline Hypothesis No. & Structural Relationship & $\begin{array}{l}\text { Standardized } \\
\text { Coefficients }\end{array}$ & Robust $t$-Value & Conclusion \\
\hline H6 & SOB-FP & -0.055 & -0.826 & Not Accepted \\
\hline $\mathrm{H} 7$ & SOB-MP & 0.304 * & 5.424 & Accepted \\
\hline $\mathrm{H} 8$ & SOB-OR & 0.066 & 0.949 & Not Accepted \\
\hline H9 & SOB-OC & 0.610 * & 7.562 & Accepted \\
\hline H10 & MP-FP & 0.648 * & 10.519 & Accepted \\
\hline H11 & OR-MP & 0.489 * & 10.167 & Accepted \\
\hline H12 & OC-OR & 0.673 * & 6.742 & Accepted \\
\hline \multicolumn{5}{|c|}{ Fit Results } \\
\hline$\chi^{2(d f) ; p \text {-Value }}$ & $\chi^{2 / d f}$ & TLI & RMSEA & RMR \\
\hline 954.102 (319); 0.000 & 2.991 & 0.94 & 0.008 & 0.036 \\
\hline
\end{tabular}

\section{Discussion}

\subsection{Research Implications}

In accordance with the aims of this investigation, our study provides relevant empirical insights into stakeholder-oriented behavior antecedents and their consequences on business performance, based on a CSR approach. Hence, two conceptual models (SO model and P model) have been tested, namely one for analyzing stakeholder-oriented behavior antecedents, and another for testing stakeholder-oriented behavior effects on business performance. These were assessed using indicators such as financial and market performance, organization reputation, and organizational commitment.

The SO model estimation revealed that behavioral norms and artifacts have a positive effect on stakeholder-oriented behavior. These results confirm findings from numerous prior studies $[7,8,25,29,55,64,83]$, which posit that behavioral norms constitute rules that foster acceptable individual behavior. Thus, organizations use norms to encourage employees to adopt appropriate attitudes. Furthermore, prior studies such as Smircich [78], Schein [67], and Hatch [80] emphasize that artifacts play a crucial role in employee behavior, since they enhance employee understanding of what the organization expects from their actions. In turn, shared basic values are positively related to behavioral norms, with both variables strongly related to one another. In line with prior research [48,75], shared basic values are the basis of the behavioral norms developed according to accepted values in the organization. Nevertheless, the SO model estimation shows that shared basic values and behavioral norms are not predictors of artifacts. Although these results are inconsistent with prior investigations $[8,48,67]$, this inconsistency may be due to artifacts. Notwithstanding they are visible, are not always easy for organization members to understand, making it difficult to interpret both values and norms which an organization wishes to communicate [136]. Thus, it is likely that there is a disjunction between artifacts and the values and the norms.

Furthermore, the results from the P model estimation indicate that stakeholder-oriented behavior have positive effects on both market performance and organizational commitment. Indeed, prior investigations have confirmed that stakeholder-oriented behavior is an antecedent of both market performance $[48,91]$ and organizational commitment $[26,40,86]$.

Conversely, the results also show that stakeholder-oriented behavior is not an antecedent of both financial performance and organizational reputation. Although the literature review confirmed 
the association between stakeholder-oriented behavior and financial performance, our results nevertheless correspond to those of some prior studies [92,137], which have also failed to find any such direct relationship. Likewise, the results of the limited prior research $[8,46,56,60]$ emphasize the existence of a significative relationship between stakeholder-oriented behavior and organizational reputation. These investigations posit that stakeholder-oriented behavior retains and develops the relationships with stakeholders based on both trust and cooperation. These in turn contribute positively to organizational reputation. Nevertheless, no investigation has found opposing results. Our findings may be due to our conceptual model simultaneously including both organizational commitment as an explained variable through stakeholder-oriented behavior, and organizational commitment as an antecedent of organizational reputation. Thus, it is likely that there was an overall mediation effect of organizational commitment between stakeholder-oriented behavior and organizational reputation. In this case, organizational reputation would be affected indirectly by stakeholder-oriented behavior through organizational commitment. This possibility is in line with Walsh et al. [121], who argue that organizational reputation stems from employee-client interactions, so that stakeholder-oriented behavior should ensure that employee actions address satisfaction and trust generation on the part of stakeholders. Thus, paying attention to employee satisfaction and their capacities is extremely relevant in order to achieve positive employee-client interactions and in turn, enhance favorable organizational reputation [121]. In this vein, Helm [102] stresses that organizational reputation management should consider actions aimed at engaging employees [99].

Our results allow us to confirm the positive effects of (a) organizational commitment on organizational reputation, (b) organizational reputation on market performance and, lastly, (c) market performance on financial performance. Indeed, as in prior studies [101,102,120,121], our results indicate that organizational commitment is an antecedent of organizational reputation. Also in line with prior research, our findings confirmed the positive effect of organizational reputation on market performance, due to customer satisfaction, value creation for customers, customer retention, and a growing market share, which all have an important influence on market performance. In this vein, Raithel and Schwaiger [138] posit that a favorable organizational reputation has an impact on the marketplace, because of larger market shares and higher profit margins. Along the same lines, Fombrun [98], Schwaiger [105], and Schwaiger et al. [106] highlight that organizational reputation generates trust and loyalty. Furthermore, Walsh, Beatty and Holloway [139] demonstrated that reputation is strongly associated with customer satisfaction, loyalty, trust, and word of mouth. Likewise, Walsh et al. [121] argue that a high-quality product and services offering, done in a trustworthy and honest way, reduces customer transaction costs and perceived risk, thus enhancing client loyalty. Other investigations $[56,105,107]$ found that organizational reputation is positively related to customer retention capacity, independent of the product or service price $[98,103,106,107]$.

This strong association between market performance and financial performance may explain the lack of direct association between stakeholder-oriented behavior and financial performance. Indeed, in accordance with prior investigations [48,140], market performance is an antecedent of financial performance, stemming from stakeholder-oriented behavior by the company in the marketplace, which enhances both customer satisfaction and loyalty. Thus, it should be expected that the relationship between these two factors is indirect.

\subsection{Managerial Implications}

The findings from the tested stakeholder-oriented behavioral research models in the CSR context provide several relevant managerial implications. These are especially relevant for businesses that only focus on their relationships with clients and competitors. These managerial implications contribute to guiding organizational decision-making with regard to strategy design, which should include policies on CSR in order to drive organization-wide behavior toward the satisfaction of stakeholder concerns at large, and finally increase competitiveness and improve company performance. 
Moreover, the satisfaction of stakeholder needs contributes to enhancing the corporate image and increasing the knowledge base. Accordingly, the management of stakeholders' social demands is considered as a strategic factor [8] that contributes to the company success.

Consequently, managers should foster stakeholder-oriented behavior organization-wide, developing appropriate norms and using suitable artifacts to disseminate intelligence. Both are elements of the organizational culture, which contributes to guiding organizational members' behavior. These norms should develop in accordance with organizational policies defined for each stakeholder group (clients, suppliers, competitors, employees, community, ... ). Furthermore, artifacts should be properly designed so that they facilitate and ensure the communication of norms to all stakeholders.

In order to consolidate stakeholder-oriented behavior at the company, managers should collect information on stakeholder issues, disseminate this information company-wide, and both design and implement strategies to satisfy diverse stakeholder demands [141]. Stakeholder information collection should allow the identification of critical stakeholders, their demands, and the extent of organization influence in satisfying these demands. The dissemination of this information on stakeholder aims to organization members contributes to resolving stakeholder concerns [8]. This information should be disseminated through both formal and informal communication channels, in both vertical and horizontal directions [58]. Finally, managers should implement actions with the aim of improving the positive impacts on stakeholders and reducing the negative ones [8].

Since stakeholder-oriented behavior affects individual behavior, the findings from this investigation are also relevant to socially responsible human resource management. In this regard, since employees are the main stakeholder group for human resource managers, their strategies should create value for employees. Thus, human resource managers should aim their efforts at involvement and satisfying workers, using social rewards based on the well-being of employees and their families. Engaging employees in stakeholder-oriented culture generates social benefits for both the organization and the stakeholders, contributing in turn, to improving company performance [142]. Furthermore, satisfying worker concerns improves their well-being and in turn, their motivation. Motivated workers will contribute more to achieving overall stakeholder satisfaction [142], since they are more predisposed to resolving problems.

In addition, ethics-committed organizations count on loyal, committed, satisfied employees, who then tend to remain with the company [84]. A consolidated social culture encourages employees to participate dynamically in the organization, thus contributing to improving the organizational performance [143].

On balance, managers need responsive strategies which react to current stakeholder concerns. They should also implement, beyond responsive strategies, those focusing on developing actions that exceed stakeholder expectations [144]. Furthermore, these strategies and policies should encourage most companies along the value chain of the industry, improving all supply-client relationships, and yielding a higher overall performance.

\section{Conclusions}

The results of this study highlight stakeholder-oriented behavior, at the heart of a well-defined CSR strategy, which affect the organizational performance. The direct effects shown in our investigation rest on market performance and employees' organizational commitment. Furthermore, our findings indicate that organizational commitment is positively related to organizational reputation, and simultaneously, organizational reputation is also an antecedent of market performance, in turn a predictor of financial performance. All these relationships encourage us to think that stakeholder-oriented behavior indirectly affects financial performance and organizational reputation through market performance and organizational commitment, respectively.

Accordingly, achieving stakeholder-oriented behavior organization-wide is only possible if an organizational culture, oriented towards stakeholders, is achieved. Regarding our results, 
stakeholder-oriented behavior is directly explained by both behavioral norms and artifacts. In turn, shared basic values are an antecedent of behavioral norms.

As indicated, companies can enhance their performance through both an appropriate organizational culture and behavior that is stakeholder-minded. Both should encourage member organization-wide to behave in a proactive manner in order to satisfy diverse stakeholder concerns. This aim will be achieved by developing an organizational culture based on behavioral norms in accordance with shared basic values, in a CSR management context. These behavioral norms should be disseminated through appropriate artifacts for conveying knowledge to members organizational-wide, and fostering their behavior in a stakeholder-minded manner. In this way, managers may generate a stakeholder-oriented atmosphere at the company, which will directly and indirectly contribute to improving enterprise performance, such as financial and market performance, reputation, and employee commitment to the organization.

This study has several limitations which should be taken into account when interpreting the research implications. First, the analysis is based on self-reported data, relying on managers' intuitive answers. These responses may be conditioned to the respondent intentions to safeguard the company image. In order to amend this potential bias, it would be desirable to use a multi-informant data-collection method. Another limitation to consider is that the investigation was conducted among Colombian companies. Since CSR efforts depend highly on national cultural aspects, cross-country research would enhance the generalization of the findings. Finally, a moderation analysis based on different firm sizes would shed more light on the effect of sustainability efforts on organizational performance.

Author Contributions: Conceptualization, C.F.-S. and L.A.M.-Q.; Methodology, Software, Validation and Formal Analysis, C.F.-S.; Data collection, L.A.M.-Q.; All authors contributed to Writing-Original Draft Preparation and Writing-Review \& Editing.

Funding: This research received no external funding.

Conflicts of Interest: The authors declare no conflict of interest.

\section{References}

1. Skouloudis, A.; Avlonitis, G.J.; Malesios, C.; Evangelinos, K. Priorities and perceptions of corporate social responsibility: Insights from the perspective of Greek business professionals. Manag. Decis. 2015, 53, $375-401$. [CrossRef]

2. Baden, D.; Harwood, I.A. Terminology matters: A critical exploration of corporate social responsibility terms. J. Bus. Ethics 2013, 116, 615-627. [CrossRef]

3. Skouloudis, A.; Evangelinos, K. Exogenously driven CSR: Insights from the consultants' perspective. Bus. Ethics Eur. Rev. 2014, 23, 258-270. [CrossRef]

4. Khalid, R.U.; Seuring, S.; Beske, P.; Land, A.; Yawar, S.A.; Wagner, R. Putting sustainable supply chain management into base of the pyramid research. Supply Chain Manag. 2015, 20, 681-696. [CrossRef]

5. Bulgacov, S.; Ometto, M.P.; May, M.R. Differences in sustainability practices and stakeholder involvement. Soc. Responsib. J. 2015, 11, 149-160. [CrossRef]

6. Samant, S.M.; Sangle, S. A selected literature review on the changing role of stakeholders as value creators. J. Sci. Technol. Sustain. Dev. 2016, 13, 100-119. [CrossRef]

7. Ferrell, O.C.; Gonzalez-Padron, T.L.; Hult, G.T.M.; Maignan, I. From market orientation to stakeholder orientation. J. Public Policy Mark. 2010, 29, 93-96. [CrossRef]

8. Maignan, I.; Gonzalez-Padron, T.L.; Hult, G.T.M.; Ferrell, O.C. Stakeholder orientation: Development and testing of a framework for socially responsible marketing. J. Strateg. Mark. 2011, 19, 313-338. [CrossRef]

9. Patel, V.K. Extended Stakeholder Orientation: Influence on Innovation Orientation and Firm Performance. Dissertations, Theses and Capstone Projects. Doctor of Business Administration (DBA); Kennesaw State University: Kennesaw, GA, USA, 2012; Available online: https:/ / digitalcommons.kennesaw.edu/etd/501 (accessed on 17 November 2017).

10. Gibson, K. The moral basis of stakeholder theory. J. Bus. Ethics 2000, 26, 245-257. [CrossRef] 
11. Littau, P.; Jujagiri, N.J.; Adlbrecht, G. 25 Years of stakeholders' theory in project management literature (1984-2009). Proj. Manag. J. 2010, 41, 17-29. [CrossRef]

12. Garvare, R.; Johansson, P. Management for sustainability-A stakeholder theory. Total Qual. Manag. 2010, 21, 737-744. [CrossRef]

13. Freeman, R.E. Strategic Management: A Stakeholder Approach; Pitman: Boston, MA, USA, 1984; ISBN 100273019139.

14. Freeman, R.E.; Harrison, J.; Wicks, A.; Parmar, B.; de Colle, S. Stakeholder Theory: The State of the Art; Cambridge University Press: Cambridge, UK, 2010; ISBN -13 978-0-521-19081-7.

15. Donaldson, T.; Preston, L.E. The stakeholder theory of the corporation: Concepts, evidence and implications. Acad. Manag. Rev. 1995, 20, 65-91. [CrossRef]

16. Kochan, T.A.; Rubinstein, S.A. Toward a stakeholder theory of the firm: The Saturn partnership. Organ. Sci. 2000, 11, 367-386. [CrossRef]

17. Sachs, S.; Ruhli, E. Changing managers' values towards a broader stakeholder orientation. Corp. Gov. Int. J. Bus. Soc. 2005, 5, 89-98. [CrossRef]

18. Clarkson, M.E. A stakeholder framework for analyzing and evaluating corporate social performance. Acad. Manag. Rev. 1995, 20, 92-117. [CrossRef]

19. Freeman, R.; Wicks, A.C.; Parmar, B. Stakeholder theory and the corporate objective revisited. Organ. Sci. 2004, 15, 364-369. [CrossRef]

20. Harrison, J.; Bosse, D.; Phillips, R. Managing for stakeholders, stakeholder utility functions, and competitive advantage. Strateg. Manag. J. 2010, 31, 58-74. [CrossRef]

21. Post, J.; Preston, L.; Sachs, S. Managing the extended enterprise: The new stakeholder view. Calif. Manag. Rev. 2002, 45, 6-28. [CrossRef]

22. Aguilera, R.V.; Rupp, D.E.; Williams, C.A.; Ganapathi, J. Putting the S back in corporate social responsibility: A multilevel theory of social change in organizations. Acad. Manag. Rev. 2007, 32, 836-863. [CrossRef]

23. Barrena-Martinez, J.; López-Fernández, M.; Romero-Fernandez, P.M. Drivers and Barriers in Socially Responsible Human Resource Management. Sustainability 2018, 10, 1532. [CrossRef]

24. Barrena-Martínez, J.; López-Fernández, M.; Romero-Fernández, P.M. Corporate social responsibility: Evolution through institutional and stakeholder perspectives. Eur. J. Manag. Bus. Econ. 2016, 25, 8-14. [CrossRef]

25. Maignan, I.; Ferrell, O.C. Corporate social responsibility and marketing: An integrative framework. J. Acad. Mark. Sci. 2004, 32, 3-19. [CrossRef]

26. Narver, J.C.; Slater, S.F. The effect of a market orientation on business profitability. J. Mark. 1990, 54, $20-35$. [CrossRef]

27. Calantone, R.J.; Cavusgil, S.T.; Zhao, Y. Learning orientation, firm innovation capability, and firm performance. Ind. Mark. Manag. 2002, 31, 515-524. [CrossRef]

28. Sinkula, J.M.; Baker, W.E.; Noordewier, T. A framework for market-based organizational learning: Linking values, knowledge, and behaviour. J. Acad. Mark. Sci. 1997, 25, 305-318. [CrossRef]

29. Slater, S.F.; Narver, J.C. Market orientation and the learning organization. J. Mark. 1995, 59, 63-74. [CrossRef]

30. Barney, J. Firm resources and sustained competitive advantage. J. Manag. 1991, 17, 99-120. [CrossRef]

31. Gill, S.J. Developing a Learning Culture in Nonprofit Organizations; Sage: Thousand Oaks, CA, USA, 2009; ISBN 1412967678.

32. Han, X.; Hansen, E.; Panwar, R.; Hamner, R.; Orozco, N. Connecting market orientation, learning orientation and corporate social responsibility implementation: Is innovativeness a mediator? Scand. J. For. Res. 2013, 28, 784-796. [CrossRef]

33. Wagner, B.; Svensson, G. A framework to navigate sustainability in business networks: The transformative business sustainability (TBS) model. Eur. Bus. Rev. 2014, 26, 340-367. [CrossRef]

34. Basu, K.; Palazzo, G. Corporate social responsibility: A process model of sensemaking. Acad. Manag. Rev. 2008, 33, 122-136. [CrossRef]

35. Bower, J.L.; Paine, L.S. The error at the heart of corporate leadership. Harv. Bus. Rev. 2017, 95, 50-60. Available online: https:/ /hbr.org/2017/05/managing-for-the-long-term (accessed on 20 February 2018).

36. Campbell, J.L. Why would corporations behave in socially responsible ways? An institutional theory of corporate social responsibility. Acad. Manag. Rev. 2007, 32, 946-967. [CrossRef]

37. Jaworski, B.J.; Kohli, A.K. Market orientation: Review, refinement, and roadmap. J. Mark. Focus. Manag. 1996, 1, 119-135. [CrossRef] 
38. Kohli, A.K.; Jaworski, B.J. Market orientation: The construct, research propositions, and managerial implications. J. Mark. 1990, 54, 1-18. [CrossRef]

39. Ruekert, R.W. Developing a market orientation: An organizational strategy perspective. Int. J. Res. Mark. 1992, 9, 225-245. [CrossRef]

40. Slater, S.F.; Narver, J.C. Does competitive environment moderate the market orientation-performance relationship? J. Mark. 1994, 58, 46-55. [CrossRef]

41. Svensson, G.; Høgevold, N.; Padin, C.; Ferro, C.; Sosa Varela, J.C.; Wagner, B. Framing stakeholder considerations and business sustainability efforts: A construct, its dimensions and items. J. Bus. Ind. Mark. 2016, 31, 287-300. [CrossRef]

42. Van Marrewijk, M. Concepts and definitions of CSR and corporate sustainability: Between agency and communion. J. Bus. Ethics 2003, 44, 95-105. [CrossRef]

43. Freeman, R.E. The politics of stakeholder theory: Some future directions. Bus. Ethics Q. 1994, 4, 409-421. [CrossRef]

44. Harrison, J.S.; Wicks, A.C. Stakeholder theory, value, and firm performance. Bus. Ethics Q. 2013, 23, 97-124. [CrossRef]

45. Jones, T.M. Instrumental stakeholder theory: A synthesis of ethics and economics. Acad. Manag. Rev. 1995, 20, 404-437. [CrossRef]

46. Jones, T.M.; Wicks, A.C. Convergent stakeholder theory. Acad. Manag. Rev. 1999, 24, 206-221. [CrossRef]

47. Burke, L.; Logsdon, J.M. How corporate social responsibility pays off. Long Range Plan. 1996, 29 , 495-502. [CrossRef]

48. Homburg, C.; Pflesser, C. A multiple-layer model of market-oriented organizational culture: Measurement issues and performance outcomes. J. Mark. Res. 2000, 37, 449-462. [CrossRef]

49. Grinstein, A. The effect of market orientation and its components on innovation consequences: A meta-analysis. J. Acad. Mark. Sci. 2008, 36, 166-173. [CrossRef]

50. Laplume, A.; Sonpar, K.; Litz, R. Stakeholder theory: Reviewing a theory that moves us. J. Manag. 2008, 34, 1152-1189. [CrossRef]

51. Ostergaard, C.; Schindele, I.; Vale, B. Social Capital and the Viability of Stakeholder-Oriented Firms: Evidence from Savings Banks. Rev. Financ. 2016, 20, 1673-1718. [CrossRef]

52. Jensen, M.C. Value maximization, stakeholder theory, and the corporate objective function. J. Appl. Corp. Financ. 2001, 14, 8-21. [CrossRef]

53. Greenley, G.; Graham, J.; John, M. Market orientation in a multiple stakeholder orientation context: Implications for marketing capabilities and assets. J. Bus. Res. 2005, 58, 1483-1494. [CrossRef]

54. Ruf, B.M.; Muralidhar, K.; Brown, R.M.; Janney, J.J.; Paul, K. An empirical investigation of the relationship between change in corporate social performance and financial performance: A stakeholder theory perspective. J. Bus. Ethics 2001, 32, 143-156. [CrossRef]

55. Matsuno, K.; Mentzer, J.T.; Rentz, J.O. A conceptual and empirical comparison of three market orientation scales. J. Bus. Res. 2005, 58, 1-8. [CrossRef]

56. Fombrun, C.; Van Riel, C. The reputational landscape. Corp. Reput. Rev. 1997, 1, 1-13. [CrossRef]

57. Gray, B.J.; Hooley, G.J. Guest editorial: Market orientation and service firm performance-a research agenda. Eur. J. Mark. 2002, 36, 980-989. [CrossRef]

58. Kohli, A.K.; Jaworski, B.J.; Kumar, A. MARKOR: A measure of market orientation. J. Mark. Res. 1993, 30, 467-477. [CrossRef]

59. Yau, O.H.; Chow, R.P.; Sin, L.Y.; Tse, A.C.; Luk, C.L.; Lee, J.S. Developing a scale for stakeholder orientation. Eur. J. Mark. 2007, 41, 1306-1327. [CrossRef]

60. Fombrun, C.J.; Gardberg, N.A.; Sever, J.M. The Reputation Quotient ${ }^{\mathrm{SM}}$ : A multi-stakeholder measure of corporate reputation. J. Brand Manag. 2000, 7, 241-255. [CrossRef]

61. Jaworski, B.J.; Kohli, A.K. Market orientation: Antecedents and consequences. J. Mark. 1993, 57, 53-70. [CrossRef]

62. Arditi, D.; Nayak, S.; Damci, A. Effect of organizational culture on delay in construction. Int. J. Proj. Manag. 2017, 35, 136-147. [CrossRef]

63. Cameron, K.S.; Quinn, R.E. Diagnosing and Changing Organizational Culture: Based on the Competing Values Framework; John Wiley and Sons: San Francisco, CA, USA, 2011; ISBN -10 0-7879-8283-0. 
64. Schein, E.H. Organizational Culture and Leadership, 3rd ed.; Jossey-Bass: San Francisco, CA, USA, 2006; ISBN 978-0-787-98505-9.

65. Deshpandé, R.; Webster, F.E., Jr. Organizational culture and marketing: Defining the research agenda. J. Mark. 1989, 53, 3-15. [CrossRef]

66. George, J.M.; Jones, G. Understanding and Managing Organizational Behavior, 6th ed.; Prentice Hall: Upper Saddle River, NJ, USA, 2010; ISBN 978-0-13-612443-6.

67. Schein, E.H. Coming to a new awareness of organizational culture. Sloan Manag. Rev. 1984, 25, 3-16. Available online: http://www.sietmanagement.fr/wp-content/uploads/2016/04/culture_schein.pdf (accessed on 14 March 2017).

68. Napitupulu, I.H. Organizational Culture in Management Accounting Information System: Survey on State-owned Enterprises (SOEs) Indonesia. Glob. Bus. Rev. 2018, 19, 556-571. [CrossRef]

69. Carroll, A.B. Corporate social responsibility. The centerpiece of competing and complementary frameworks. Organ. Dyn. 2015, 44, 87-96. [CrossRef]

70. Ford, R.C.; Richardson, W.D. Ethical decision making: A review of the empirical literature. J. Bus. Ethics 1994, 13, 205-221. [CrossRef]

71. Bovée, C.; Thill, J. Business Communication Today, 13th ed.; Pearson: Harlow, UK, 2016; ISBN 9780133851915.

72. Tourish, D.; Hargie, O. Key Issues in Organizational Communication; Routledge: London, UK, 2004; ISBN 0415260949.

73. Kalla, H.K. Integrated internal communications: A multidisciplinary perspective. Corp. Commun. Int. J. 2005, 10, 302-314. [CrossRef]

74. Argenti, P.A.; Forman, J. The Power of Corporate Communication: Crafting the Voice and Image of your Business; McGraw Hill: New York, NY, USA, 2002; ISBN 0071379495.

75. O'Reilly, C. Corporations, culture, and commitment: Motivation and social control in organizations. Calif. Manag. Rev. 1989, 31, 9-25. [CrossRef]

76. Luthans, F. Organizational Behavior: An Evidence-Based Approach, 12th ed.; McGraw-Hill Irwin: New York, NY, USA, 2011; ISBN 0071289399.

77. Trice, H.M.; Beyer, J.M. The Cultures of Work Organizations; Prentice-Hall, Inc.: Englewood Cliffs, NJ, USA, 1993; ISBN 0131914383.

78. Smircich, L. Concepts of culture and organizational analysis. Adm. Sci. Q. 1983, 28, 339-358. [CrossRef]

79. Dandridge, T.C.; Mitroff, I.; Joyce, W.F. Organizational symbolism: A topic to expand organizational analysis. Acad. Manag. Rev. 1980, 5, 77-82. [CrossRef]

80. Hatch, M.J. The dynamics of organizational culture. Acad. Manag. Rev. 1993, 18, 657-693. [CrossRef]

81. Alles, M. Comportamiento Organizacional: Cómo Lograr un Cambio Cultural a Través de Gestión por Competencias; Ediciones Granica: Buenos Aires, Argentina, 2013; ISBN 9506417121.

82. Cole, G. Organisational Behaviour: Theory and Practice; Thomson Learning: London, UK, 1995; ISBN 0826453872.

83. Heide, J.B.; John, G. Do norms matter in marketing relationships? J. Mark. 1992, 56, 32-44. [CrossRef]

84. Treviño, L.K.; Butterfield, K.D.; McCabe, D.L. The ethical context in organizations: Influences on employee attitudes and behaviors. Bus. Ethics Q. 1998, 8, 447-476. [CrossRef]

85. Rego, A.; Leal, S.; Cunha, M.P.; Faria, J.; Pinho, C. How the perceptions of five dimensions of corporate citizenship and their inter-inconsistencies predict affective commitment? J. Bus. Ethics 2010, 94, 107-127. [CrossRef]

86. Siguaw, J.A.; Brown, G.; Widing, R.E. The influence of the market orientation of the firm on sales force behavior and attitudes. J. Mark. Res. 1994, 31, 106-116. [CrossRef]

87. Ogbonna, E.; Lloyd, C.H. Managing organizational culture: Insights from the hospitality industry. Hum. Resour. Manag. J. 2002, 12, 33-53. [CrossRef]

88. Ogbonna, E.; Wilkinson, B. Corporate strategy and corporate culture: The view from the checkout. Person Rev. 1990, 19, 9-15. [CrossRef]

89. Raju, P.S.; Lonial, S.C.; Gupta, Y.P.; Ziegler, C. The relationship between market orientation and performance in the hospital industry: A structural equations modeling approach. Health Care Manag. Sci. 2000, 3, $237-247$. [CrossRef] [PubMed]

90. Narver, J.C.; Slater, S.F. Product-market strategy and performance: An analysis of the Miles and Snow strategy types. Eur. J. Mark. 1993, 27, 33-51. [CrossRef] 
91. Ngai, J.; Ellis, P. Market orientation and business performance: Some evidence from Hong Kong. Int. Mark. Rev. 1998, 15, 119-139. [CrossRef]

92. Duesing, R.J. Stakeholder Orientation and its Impact on Performance in Small Businesses. Ph.D. Thesis, Degree of Doctor of Philosophy, Oklahoma State University, Stillwater, OK, USA, 2009.

93. Berman, S.L.; Wicks, A.C.; Kotha, S.; Jones, T.M. Does stakeholder orientation matter? The relationship between stakeholder management models and firm financial performance. Acad. Manag. J. 1999, 42, 488-506. [CrossRef]

94. Choi, J.; Wang, H. Stakeholder relations and the persistence of corporate financial performance. Strateg. Manag. J. 2009, 30, 895-907. [CrossRef]

95. Hillman, A.J.; Keim, G.D. Shareholder value, stakeholder management, and social issues: What's the bottom line? Strateg. Manag. J. 2001, 22, 125-139. [CrossRef]

96. Panwar, R.; Nybakk, E.; Hansen, E.; Pinkse, J. Does the business case matter? The effect of a perceived business case on small firms' social engagement. J. Bus. Ethics 2017, 144, 597-608. [CrossRef]

97. Grewal, R.; Tansuhaj, P. Building organizational capabilities for managing economic crisis: The role of market orientation and strategic flexibility. J. Mark. 2001, 65, 67-80. [CrossRef]

98. Fombrun, C. Reputation: Realizing Value from the Corporate Image; Harvard Business School Press: Boston, MA, USA, 1996; ISBN 0875846335.

99. Gotsi, M.; Wilson, A.M. Corporate reputation: Seeking a definition. Corp. Commun. Int. J. 2001, 6, 24-30. [CrossRef]

100. Hall, R. A framework linking intangible resources and capabilities to sustainable competitive advantage. Strateg. Manag. J. 1993, 14, 607-618. [CrossRef]

101. Fombrun, C.J.; Ponzi, L.J.; Newburry, W. Stakeholder tracking and analysis: The RepTrak ${ }^{\circledR}$ system for measuring corporate reputation. Corp. Reput. Rev. 2015, 18, 3-24. [CrossRef]

102. Helm, S. Employees' awareness of their impact on corporate reputation. J. Bus. Res. 2011, 64, 657-663. [CrossRef]

103. Fombrun, C.; Shanley, M. What's in a name? Reputation building and corporate strategy. Acad. Manag. J. 1990, 33, 233-258. [CrossRef]

104. Flanagan, D.J.; O'shaughnessy, K.C.; Palmer, T.B. Re-assessing the relationship between the fortune reputation data and financial performance: Overwhelming influence or just a part of the puzzle? Corp. Reput. Rev. 2011, 14, 3-14. [CrossRef]

105. Schwaiger, M. Components and parameters of corporate reputation-An empirical study. Schmalenbach Bus. Rev. 2004, 56, 46-71. [CrossRef]

106. Schwaiger, M.; Raithel, S.; Schloderer, M. Recognition or rejection-How a company's reputation influences stakeholder behaviour. In Reputation Capital; Klewes, J., Wreschniok, R., Eds.; Springer: Berlin/Heidelberg, Germany, 2009; pp. 39-55. ISBN 978-3-642-01629-5.

107. Helm, S. One reputation or many? Comparing stakeholders' perceptions of corporate reputation. Corp. Commun. Int. J. 2007, 12, 238-254. [CrossRef]

108. Mowday, R.; Porter, L.; Steers, R. Employee-Organization Linkages: The Psychology of Commitment, Absenteeism, and Turnover, 1st ed.; Academic Press: New York, NY, USA, 1982; ISBN 9781483267395.

109. Meyer, J.P.; Allen, N.J. A three-component conceptualization of organizational commitment. Hum. Resour. Manag. Rev. 1991, 1, 61-89. [CrossRef]

110. Meyer, J.P.; Herscovitch, L. Commitment in the workplace: Toward a general model. Hum. Resour. Manag. Rev. 2001, 11, 299-326. [CrossRef]

111. Van Dyne, L.; LePine, J.A. Helping and voice extra-role behaviors: Evidence of construct and predictive validity. Acad. Manag. J. 1998, 41, 108-119. [CrossRef]

112. Sandra, L.R.; O'Leary-Kelly, A.M. Monkey see, monkey do: The influence of work groups on the antisocial behavior of employees. Acad. Manag. J. 1998, 41, 658-672. [CrossRef]

113. Lapointe, E. Examination of the relationships between servant leadership, organizational commitment, and voice and antisocial behaviors. J. Bus. Ethics 2018, 148, 99-115. [CrossRef]

114. Stanley, L.; Vandenberghe, C.; Vandenberg, R.; Bentein, K. Commitment profiles and employee turnover. J. Vocat. Behav. 2013, 82, 176-187. [CrossRef] 
115. Bentein, K.; Vandenberg, R.; Vandenberghe, C.; Stinglhamber, F. The role of change in the relationship between commitment and turnover: A latent growth modeling approach. J. Appl. Psychol. 2005, 90, 468-482. [CrossRef] [PubMed]

116. Morrison, E.W. Employee voice behavior: Integration and directions for future research. Acad. Manag. Ann. 2011, 5, 373-412. [CrossRef]

117. Lok, P.; Crawford, J. The effect of organisational culture and leadership style on job satisfaction and organisational commitment: A cross-national comparison. J. Manag. Dev. 2004, 23, 321-338. [CrossRef]

118. Themba, G.; Marandu, E.E. The effects of market orientation on employees: A study of retail organizations in Botswana. Int. Bus. Res. 2013, 6, 130-136. [CrossRef]

119. Powpaka, S. How market orientation affects female service employees in Thailand. J. Bus. Res. 2006, 59, 54-61. [CrossRef]

120. Lau, K.C.; Lim, L. Transformational branding for B2B business: Protective packaging company. Asia Pac. J. Mark. Logist. 2018, 30, 517-530. [CrossRef]

121. Walsh, G.; Mitchell, V.W.; Jackson, P.R.; Beatty, S.E. Examining the antecedents and consequences of corporate reputation: A customer perspective. Br. J. Manag. 2009, 20, 187-203. [CrossRef]

122. Satorra, A.; Bentler, P.M. Scaling Corrections for Chi Square Statistics in Covariance Structure Analysis. In American Statistical Associations Proceedings of the Business and Economic Sections; American Statistical Association: Alexandria, VA, USA, 1988; pp. 308-313. ISBN -10 9998335418.

123. Johnson, R.E.; Rosen, C.C.; Chang, C.H. To aggregate or not to aggregate: Steps for developing and validating higher-order multidimensional constructs. J. Bus. Psychol. 2011, 26, 241-248. [CrossRef]

124. Fuller, C.M.; Simmering, M.J.; Atinc, G.; Atinc, Y.; Babin, B.J. Common methods variance detection in business research. J. Bus. Res. 2016, 69, 3192-3198. [CrossRef]

125. Harman, H.H. Modern Factor Analysis, 2nd ed.; University of Chicago Press: Chicago, IL, USA, 1976; ISBN -10 0226316521.

126. Hair, J.F.; Anderson, R.E.; Babin, B.J.; Black, W.C. Multivariate Data Analysis, 7th ed.; Pearson: Upper Saddle River, NJ, USA, 2009; ISBN -10 0138132631.

127. Steenkamp, J.-B.; van Trijp, H.C.M. The use of lisrel in validating marketing construct. Int. J. Res. Mark. 1991, 8, 283-299. [CrossRef]

128. Fornell, C.; Larcker, D.F. Structural equation models with unobservable variables and measurement error: Algebra and statistics. J. Mark. Res. 1981, 18, 382-388. [CrossRef]

129. Bentler, P.M. Fit indexes, Lagrange multipliers, constraint changes and incomplete data in structural models. Multivar. Behav. Res. 1990, 25, 163-172. [CrossRef]

130. Bentler, P.M.; Bonett, D.G. Significance tests and goodness of fit in the analysis of covariance structures. Psychol. Bull. 1980, 88, 588-606. [CrossRef]

131. Byrne, B.M. Structural Equation Modeling with Amos: Basic Concepts, Applications, and Programming, 3rd ed.; Routledge/Taylor y Francis Group: New York, NY, USA, 2016; ISBN -10 1138797022.

132. Carmines, E.G.; McIver, J.P. Analyzing models with unobserved variables. In Social Measurement: Current Issues, 1st ed.; Bohrnstedt, G.W., Borgatta, E.F., Eds.; Sage Publications: Beverly Hills, CA, USA, 1981; pp. 65-115. ISBN -10 0803915969.

133. Hoyle, R.H.; Panter, A.T. Writing about structural equation models. In Structural Equation Modeling: Concepts, Issues, and Applications; Hoyle, R.H., Ed.; Sage: Thousand Oaks, CA, USA, 1995; pp. 158-176. ISBN 0803953186.

134. Schumacker, R.E.; Lomax, R.G. A Beginner's Guide to Structural Equation Modeling; Lawrence Erlbaum Associates: Mahwah, NJ, USA, 2004; ISBN 100805840184.

135. James, L.R.; Mulaik, S.A.; Brett, J.M. Causal Analysis: Assumptions, Models, and Data; Sage: Beverly Hills, CA, USA, 1982; ISBN 100803918682.

136. Aier, S. The role of organizational culture for grounding, management, guidance and effectiveness of enterprise architecture principles. Inf. Syst. e-Bus. Manag. 2014, 12, 43-70. [CrossRef]

137. Langerak, F.; den Hartigh, E. Managing increasing returns. Eur. Manag. J. 2001, 19, 370-378. [CrossRef]

138. Raithel, S.; Schwaiger, M. The effects of corporate reputation perceptions of the general public on shareholder value. Strateg. Manag. J. 2015, 36, 945-956. [CrossRef]

139. Walsh, G.; Beatty, S.E.; Holloway, B.B. Measuring client-based corporate reputation in B2B professional services: Scale development and validation. J. Serv. Mark. 2015, 29, 173-187. [CrossRef] 
140. Anderson, E.W.; Sullivan, M.W. The antecedents and consequences of customer satisfaction for firms. Mark. Sci. 1993, 12, 125-143. [CrossRef]

141. Mena, J.A.; Chabowski, B.R. The role of organizational learning in stakeholder marketing. J. Acad. Mark. Sci. 2015, 43, 429-452. [CrossRef]

142. Voegtlin, C.; Greenwood, M. Corporate social responsibility and human resource management: A systematic review and conceptual analysis. Hum. Resour. Manag. Rev. 2016, 26, 181-197. [CrossRef]

143. Shahzad, F.; Xiu, G.Y.; Shahbaz, M. Organizational culture and innovation performance in Pakistan's software industry. Technol. Soc. 2017, 51, 66-73. [CrossRef]

144. Heikkurinen, P.; Bonnedahl, K.J. Corporate responsibility for sustainable development: A review and conceptual comparison of market- and stakeholder-oriented strategies. J. Clean. Prod. 2013, 43, 191-198. [CrossRef]

(C) 2018 by the authors. Licensee MDPI, Basel, Switzerland. This article is an open access article distributed under the terms and conditions of the Creative Commons Attribution (CC BY) license (http://creativecommons.org/licenses/by/4.0/). 